\title{
Mid-Quaternary decoupling of sediment routing in the Nankai Forearc revealed by provenance analysis of turbiditic sands
}

\author{
Journal Article \\ Author(s): \\ Usman, Muhammed O.; Masago, Hideki; Winkler, Wilfried (D); Strasser, Michael \\ Publication date: \\ 2014-06 \\ Permanent link: \\ https://doi.org/10.3929/ethz-b-000081437
}

Rights / license:

$\underline{\text { In Copyright - Non-Commercial Use Permitted }}$

Originally published in:

International Journal of Earth Sciences 103(4), https://doi.org/10.1007/s00531-014-1011-z

Funding acknowledgement:

133481 - DYNAMITE: Dynamic Nankai Trough (Japan) and Swiss Molasse Basin: Investigating NeoTectonics, Paleo-Earthquakes and associated Geohazards (SNF) 


\title{
Mid-Quaternary decoupling of sediment routing in the Nankai Forearc revealed by provenance analysis of turbiditic sands
}

\author{
Muhammed O. Usman · Hideki Masago • \\ Wilfried Winkler $\cdot$ Michael Strasser
}

Received: 4 October 2013 / Accepted: 22 February 2014 / Published online: 20 March 2014

(C) Springer-Verlag Berlin Heidelberg 2014

\begin{abstract}
Coring during Integrated Ocean Drilling Program Expeditions 315, 316, and 333 recovered turbiditic sands from the forearc Kumano Basin (Site C0002), a Quaternary slope basin (Site C0018), and uplifted trench wedge (Site C0006) along the Kumano Transect of the Nankai Trough accretionary wedge offshore of southwest Japan. The compositions of the submarine turbiditic sands here are investigated in terms of bulk and heavy mineral modal compositions to identify their provenance and dispersal mechanisms, as they may reflect changes in regional tectonics during the past ca. 1.5 Myrs. The results show a marked change in the detrital signature and heavy mineral composition in the forearc and slope basin facies around $1 \mathrm{Ma}$. This sudden change is interpreted to reflect a major change in the sand provenance, rather than heavy mineral dissolution and/or diagenetic effects, in response to changing tectonics and sedimentation patterns. In the trenchslope basin, the sands older than $1 \mathrm{Ma}$ were probably eroded from the exposed Cretaceous-Tertiary accretionary complex of the Shimanto Belt and transported via the former course of the Tenryu submarine canyon system, which today enters the Nankai Trough northeast of the study area. In contrast, the high abundance of volcanic lithics and volcanic heavy mineral suites of the sands younger than $1 \mathrm{Ma}$ points to a strong volcanic component of sediment derived from the Izu-Honshu collision zones and probably
\end{abstract}

M. O. Usman $(\bowtie) \cdot$ W. Winkler $\cdot$ M. Strasser

Department of Earth Sciences, Geological Institute, ETH Zurich, Sonneggstrasse 5, 8092 Zurich, Switzerland

e-mail: muhammed.usman@erdw.ethz.ch

H. Masago

Center for Deep Earth Exploration, Japan Agency for Marine-

Earth Science and Technology, 3173-25 Showa-machi,

Kanazawa-ku, Yokohama, Kanagawa 236-0001, Japan funnelled to this site through the Suruga Canyon. However, sands in the forearc basin show persistent presence of blue sodic amphiboles across the $1 \mathrm{Ma}$ boundary, indicating continuous flux of sediments from the Kumano/Kinokawa River. This implies that the sands in the older turbidites were transported by transverse flow down the slope. The slope basin facies then switched to reflect longitudinal flow around $1 \mathrm{Ma}$, when the turbiditic sand tapped a volcanic provenance in the Izu-Honshu collision zone, while the sediments transported transversely became confined in the Kumano Basin. Therefore, the change in the depositional systems around $1 \mathrm{Ma}$ is a manifestation of the decoupling of the sediment routing pattern from transverse to long-distance axial flow in response to forearc high uplift along the megasplay fault.

Keywords Sand provenance $\cdot$ Nankai Trough .

NanTroSEIZE · Kumano Basin - Accretionary wedge ·

Sediment routing

\section{Introduction}

Actualistic provenance studies on a continental scale (e.g. Ingersoll 1990; Potter 1994; Critelli et al. 1997) are a powerful tool for understanding the relationship between sedimentation and tectonics. Such studies provide fundamental insights to improve our understanding of (1) the location and nature of sediment source areas, (2) the pathways by which sediment is transferred from source to depositional basin and (3) the factors (e.g. relief, climate and tectonics) that influence the composition of sedimentary rocks (Haughton et al. 1991). Recognition of diagnostic petrographic and mineralogical signatures of contrasting geodynamic settings by relating the composition of modern 


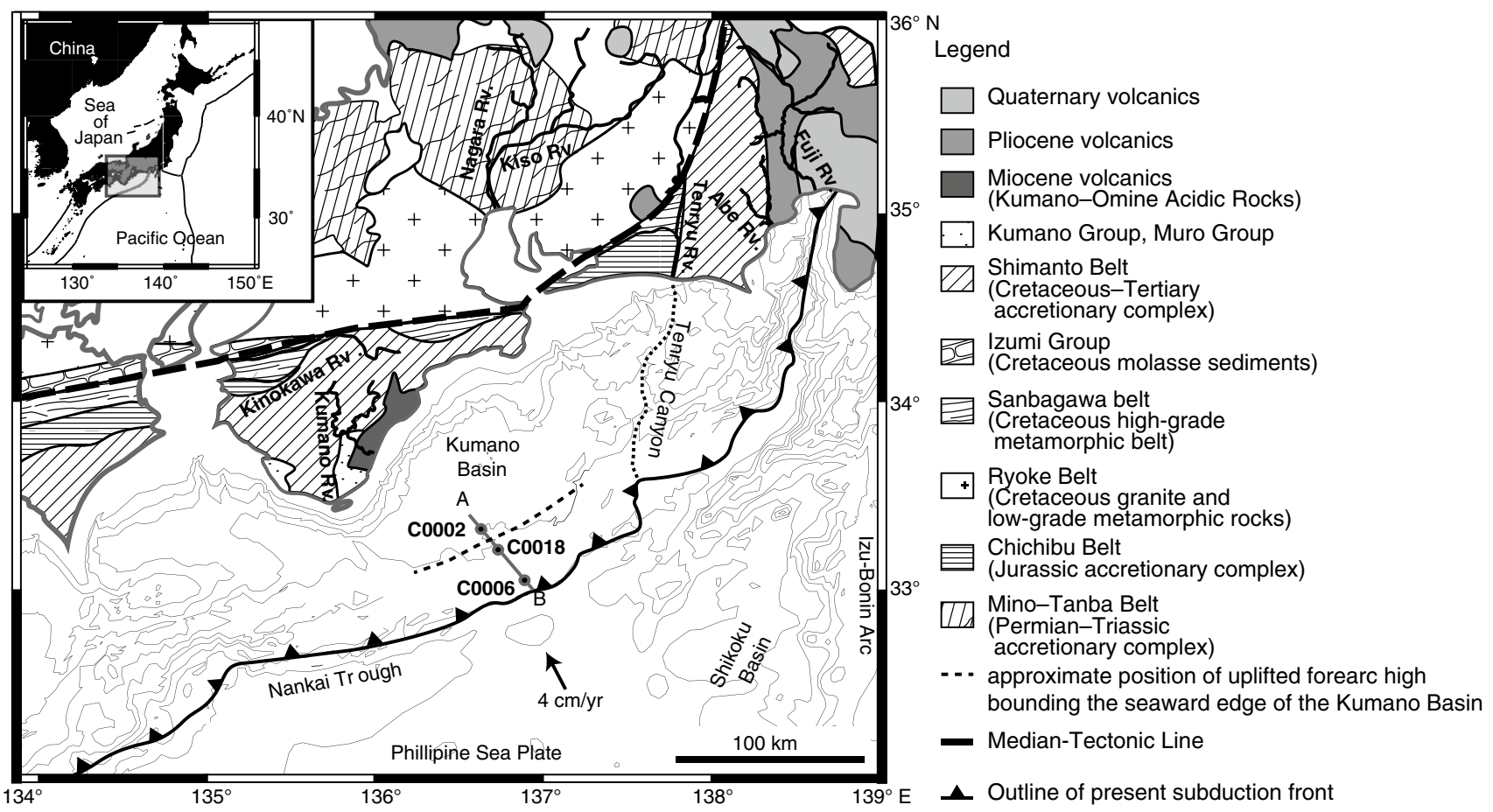

Fig. 1 Bathymetric map of the Kumano-nada and surrounding regions, and a simplified geological map of the related onshore regions. Locations of the coring Sites C0002, C0006 and C0018 are indicated. Rivers courses, in which reference sand samples were col-

sands to the geologic evolution of wide and complex source areas helps in making predictions of detrital mode trends in space and time (Garzanti et al. 2003, 2012). Materials used for provenance studies are as diverse as Quaternary clay minerals in accretionary prism (Underwood and Pickering 1996), Archean shales (McLennan et al. 1983) and soils on the moon (Basu et al. 1988).

In accretionary prisms formed along subduction zones, such as the Nankai Trough off SW Japan, complex suites of structures often develop as a result of the deformation of sediments being scraped-off from the subducting plate (e.g. Strasser et al. 2009). In such accretionary subduction zones, trench floor and oceanic plate deposits are added to the toe of the inner slope by imbricate thrusting (Karig and Sharman 1975). An important factor that controls the overall geometry and stratigraphy of an accretionary subduction margin is the type and amount of sedimentary fill in the trench, trench-slope basin and forearc basin. Sediment supply to the prism occurs mostly by sediment gravity flows, transporting sand and silt from one or more source areas into the system, and by hemipelagic sedimentation through the water column. Sedimentation is therefore controlled by climatic and tectonic conditions governing erosion and sediment transport in the source area, sediment routing system (e.g. rivers and submarine canyons), and the geometry and structural evolution of the forearc basin, outer trench lected, are also shown. Line $A-B$ shows location of seismic overview line shown in Fig. 2. Figure modified from Shipboard Scientific Party (2001)

slope and the trench slope itself (Underwood and Moore 1995). Provenance information, especially in the case of accretionary prisms, has important ramifications for assessing and evaluating the dynamic responses of prism growth and deformation to spatio-temporal variations in sediment generation and influx (Milliken et al. 2012).

The Nankai Trough region off the southwest coast of Japan (Fig. 1) is one of the most thoroughly studied subduction margins for late Cenozoic trench sedimentation and accretionary prism tectonics (Karig et al. 1975; Taira et al. 1991; Moore et al. 2001; Strasser et al. 2009; Clift et al. 2013). The flux of terrigenous sediments to the Nankai Trough is high, compared to other subduction margins such as the Barbados (Moore et al. 1988) and the neighbouring Japan Trench (von Huene and Lallemant 1990). Thus, the stratigraphy of such accretionary prisms serves as an effective modern analogue for uplifted sandstone-rich accreted terranes such as the Shimanto Belt of Japan (Taira et al. 1988). Previous work on detrital modes of sand in the Nankai Forearc region has documented a wide range in composition reflecting variable mixing of volcanic, sedimentary, metasedimentary and plutonic sources (Taira and Niitsuma 1986; Marsaglia et al. 1992; Fergusson 2003; Underwood and Fergusson 2005). Fergusson (2003) identified three sand petrofacies: volcaniclastic, quartzose and sedimenticlastic based on description of sand compositions in 
offshore Muroto and Ashizuri transects obtained by coring in Ocean Drilling Program (ODP) Leg 190. He concluded that the Izu-Honshu collision zone at the eastern end of the Nankai Trough is the provenance of the volcaniclastic sand that is rich in mafic to intermediate rock fragments in the upper Pleistocene section and demonstrated the transverse transportation of turbidites along the trough axis.

New samples and data obtained by drilling within the Integrated Ocean Drilling Program (IODP) Nankai Trough Seismogenic Zone Experiment (NanTroSEIZE) now reveal excellent recovery of basin sediments of the Kumano Forearc and the trench-slope basin along the Kumano Transect. These provide insights into the history of the basin development and change in the sediment source regions. Gulick et al. (2010), mainly based on 3D reflection seismic data, reported a regional tilting of the Kumano Forearc basin during Middle to Late Quaternary and demonstrated how this tilting resulted in the landward shifting of depocentres during uplift of the forearc high and basin infilling thereafter. The purpose of this paper is to study these hypothesized tectonic effects on sedimentation pattern in the submarine forearc with a detailed sediment provenance analyses. The objectives are (1) to document the heavy mineral and modal framework compositional data for turbiditic sands from IODP drill sites within the Kumano Forearc basin (Site C0002), the trench-slope basin and trench-wedge seaward of the forearc high (Sites C0018 and C0006, respectively) (Fig. 1), (2) to interpret sediment provenance of different lithologic units deposited in the past ca. 1.5 Myrs, (3) identify regional-scale pathways of sediment dispersal in the Nankai Trough and (4) investigate how the compositional variations between turbiditic sands and interbeds of hemipelagic muds and volcanic ash may document the change in regional tectonics.

\section{Geological framework}

Regional geology and tectonics

The geology of central and southwestern Japan consists of a wide variety of Mesozoic and early Cenozoic accretionary complexes (Maruyama et al. 1997). Several geologic terranes, referred to as "belts" in Japanese terminology, are subparallel to the Nankai Trough and are classified into an inner and outer zone, which are separated by the Median Tectonic Line (Fig. 1); (Taira and Niitsuma 1986). The inner zone which is located in the northern part of the Median Tectonic Line (Fig. 1) contains low-pressure, hightemperature metamorphic rocks of the Ryoke Belt and associated granitic rocks (Nakajima 1997). The outer zone geology, which is closely related to the provenance of the
Nankai Trough clastics, consists of slivers of high-pressure metamorphic rocks and low-grade metasedimentary strata assigned to the Sanbagawa, Chichibu and Shimanto belts (Taira et al. 1988; Higashino 1990). The Sanbagawa Belt is made up of high-pressure metamorphic rocks, probably representing a part of a Jurassic subduction complex. The Chichibu Belt is a heterogeneous geologic terrane, including a Jurassic subduction complex and a strike-slip mobile zone with exotic tectonic blocks. The dominant lithology is sandstone, slate, chert, limestone and metabasalt. The Shimanto Belt comprises a Cretaceous to Miocene subduction complex composed of sandstone, shale, chert and metabasalt (Taira and Niitsuma 1986). Tertiary to Quaternary volcanic rocks occur only in the Kyushu and Fossa Magna-Izu regions. Felsic to intermediate explosive activity characterizes the Kyushu volcanics, whereas mafic to intermediate volcanic rocks are dominant in central Japan (Taira and Niitsuma 1986).

At about 15-18 Ma, the outer trench was affected by rotation and near-trench magmatic activity (Saito et al. 1997). The Izu-Bonin Arc started colliding with the Honshu Arc at approximately $12 \mathrm{Ma}$ with four major episodes of accretion occurring at 12,7-9, 3-5 and $1 \mathrm{Ma}$ (Amano 1991). A syntaxis of the outer zone belts (Fig. 1) is one of the obvious manifestations of the collision (Takahashi and Saito 1997). New data from apatite and zircon fission track thermochronology by Clift et al. (2013) indicate that the collision has been ongoing since around $8 \mathrm{Ma}$ and the collision point migrated past the forearc. These data show that there has been no delivery of young sediments eroded from the Izu-Honshu collision zone along the trench at any time since at least $2 \mathrm{Ma}$, which would imply that these young sediments must have been accumulated close to the collision point and not distributed far along the trench (Clift et al. 2013). However, this conclusion is at variance with that of Fergusson (2003). These different observations by Clift et al. (2013) and Fergusson (2003) could be a result of different sampling resolution along the trench. Our study sites investigated here are more localized and located more than $500 \mathrm{~km}$ closer to the Izu-Hoshu collision zone than the sites studied by Clift et al. (2013) and Fergusson (2003), aiming at resolving this apparent contradiction. Also, the kinematics of the Philippine Sea Plate and recent geological evidences from paleomagnetic data and seafloor spreading studies show that the Izu Arc collision with central Japan must have occurred more recently, probably ca. 6-8 Ma. This is consistent with the inferred age of the Tanzawa Block (part of the Izu Arc) collision at $6.8 \mathrm{Ma}$ (Yamamoto and Kawakami 2005) and contradicts most published reconstructions of Japanese tectonics (e.g. Amano 1991; Saito et al. 1997; Takahashi and Saito 1997; Taira 2001; Kimura et al. 2005), many of which 
were developed prior to the collection of paleomagnetic and other data sets documenting the past history of the Philippine Sea Plate (Mahony et al. 2011).

The submerged accretionary prism of the Nankai Trough (Figs. 1, 2) formed as a result of the northwestdirected subduction of the Philippine Sea Plate beneath southwestern Japan (the Eurasian plate). The most recent phase of subduction-accretion began approximately $6 \mathrm{Ma}$ as convergence accelerated (Kamata and Kodama 1999). Today, the convergence rate is ca. $4 \mathrm{~cm} /$ year (Seno et al. 1993). The convergence direction is approximately normal to the trench, and the sediments from the Shikoku Basin are actively accreting at the deformation front (Fig. 1).

The upper slope of the Nankai Trough contains several prominent forearc basins (Muroto, Tosa and Kumano), which intercept sediments emanating from small canyons and slope gullies (Blum and Okamura 1992). The margin-perpendicular Kumano Transect, which is the focus of this study, is divided (from SE to NW) into six main morphotectonic zones: trench, frontal thrust zone (FTZ), imbricate thrust zone (ITZ), megasplay fault zone (MSFZ), forearc high and the forearc (Kumano) basin (Fig. 2a; Moore et al. 2009). In the trench zone, a thick wedge of Quaternary trench deposits overlies Miocene-Pliocene Shikoku Basin sediments and subducting igneous basement. Landward of the deformation front is the ITZ, a series of thrust packages reflecting past in-sequence thrusting and accretion, emplaced within the last $\sim 1.5$ Myrs (Strasser et al. 2009). The ITZ is overlain by Quaternary slope sediments deposited in slope basins within the ridge-basin topography typical of fold-and-thrust belts developed in many accretionary prisms. Beneath the upper slope and Kumano Basin, a regional splay fault system termed "megasplay" (Tobin and Kinoshita 2006) discontinuously cuts across the older part of the accretionary prism and overthrusts the younger slope basins (Moore et al. 2009; Strasser et al. 2009). Landward of the MSFZ and the forearc high, the Kumano Forearc basin infill comprises more than $1 \mathrm{~km}$ of Quaternary sediment. The seaward portion of the basin section is progressively tilted towards land because of repeated motion on the megasplay fault (Gulick et al. 2010).

Along this Kumano Transect, several recent IODP expeditions drilled and cored the Kumano Basin (C0002 and C0009), trench-slope basin perched on the lower slope (e.g. C0008, C0018 and C0021) and relatively recently (ca. $0.436 \mathrm{Ma}$; Screaton et al. 2009) accreted trench-wedge deposits (e.g. C0006 and C0007); (Fig. 2a, b). This study focuses on three sites that best represent the Kumano Basin, trench-slope basin and trenchwedge facies (IODP Sites C0002, C0018 and C0006, respectively).
Fig. 2 a Seismic cross section of the Nankai Trough region in the Kumano-nada area along the $A-B$ trace in Fig. 1. (Modified after Moore et al. 2009), columnar sections of Site C0002 (b), C0018 (c), and C0006 (d) showing the lithostratigraphy and integrated ages from calcareous nanofossil biostratigraphy, magnetostratigraphy and tephrochronology as determined by Expedition 315 Scientists (2009), Expedition 338 Scientists (2013), Expedition 333 Scientists (2012), and Expedition 316 Scientists (2009b), respectively. MTDs mass transport deposits

\section{Stratigraphy}

\section{Kumano Forearc basin facies (Site C0002)}

The lithostratigraphic section of the Kumano Forearc is well documented at Site C0002. At this site, which is located in the seaward (southwestern) flank of the Kumano Basin (Fig. 2), four lithostratigraphic units were recognized based on $\log$ and core data (Expedition 315 Scientists 2009). The upper three units belong to the Kumano Forearc basin facies, and the lowest Unit IV is an accretionary prism facies. Unit I (upper Kumano Basin facies: 0-135.9 m below sea floor (mbsf)) consists of Quaternary $(<0.2 \mathrm{Ma}-\mathrm{ca} .1 .08 \mathrm{Ma})$ silty clay to clayey silt with intercalations of sand and silt turbidites and volcanic ash. Unit II (lower Kumano Basin facies: 135.9-830.4 mbsf) is also of the Quaternary age (ca. 1.08-1.67 Ma) that consists of silty clay to clayey silt intercalated with sand, silty sand, silt and volcanic ash. Unit III (830.4-921.7 mbsf) comprises Pleistocene to Late Miocene (ca. 1.67-5.59 Ma) silty claystone. This unit typically lacks turbiditic sediments as are observed in Units I and II, and is interpreted as the basal forearc basin facies. Unit IV (921.7-1,025 mbsf) consists of Miocene (ca. 5.59-5.90 Ma) silty claystone to clayey siltstone intercalated with siltstone and sandstone. Rocks belonging to this unit are highly deformed and have random dipping angles and numbers of small faults suggesting that this unit is upper accretionary prism facies (Expedition 315 scientists 2009; Expedition 338 Scientists 2013).

\section{Trench-slope basin facies (Site C0018)}

At Site C0018, which penetrated the deposits of the slope basin in the middle slope (Unit 1; Expedition 333 Scientists 2012), two lithologic subunits were recognized and named Unit Ia (0-190.65 mbsf) and Unit Ib (190.65$313.65 \mathrm{mbsf}$ ). The upper Unit Ia consists of nanofossil-rich greenish grey to greyish silty clay with mostly thin intercalations of volcaniclastic sands. Bioturbation is observed in the upper part of the unit. Six intervals with evidences of mass transport deposits (MTDs) are observed within this unit (Fig. 2). The upper boundary is well defined for MTD 1, 2 and 6, and it is marked by a turbidite for 2 and 6 . The deposition of this unit occurred on a continental slope 


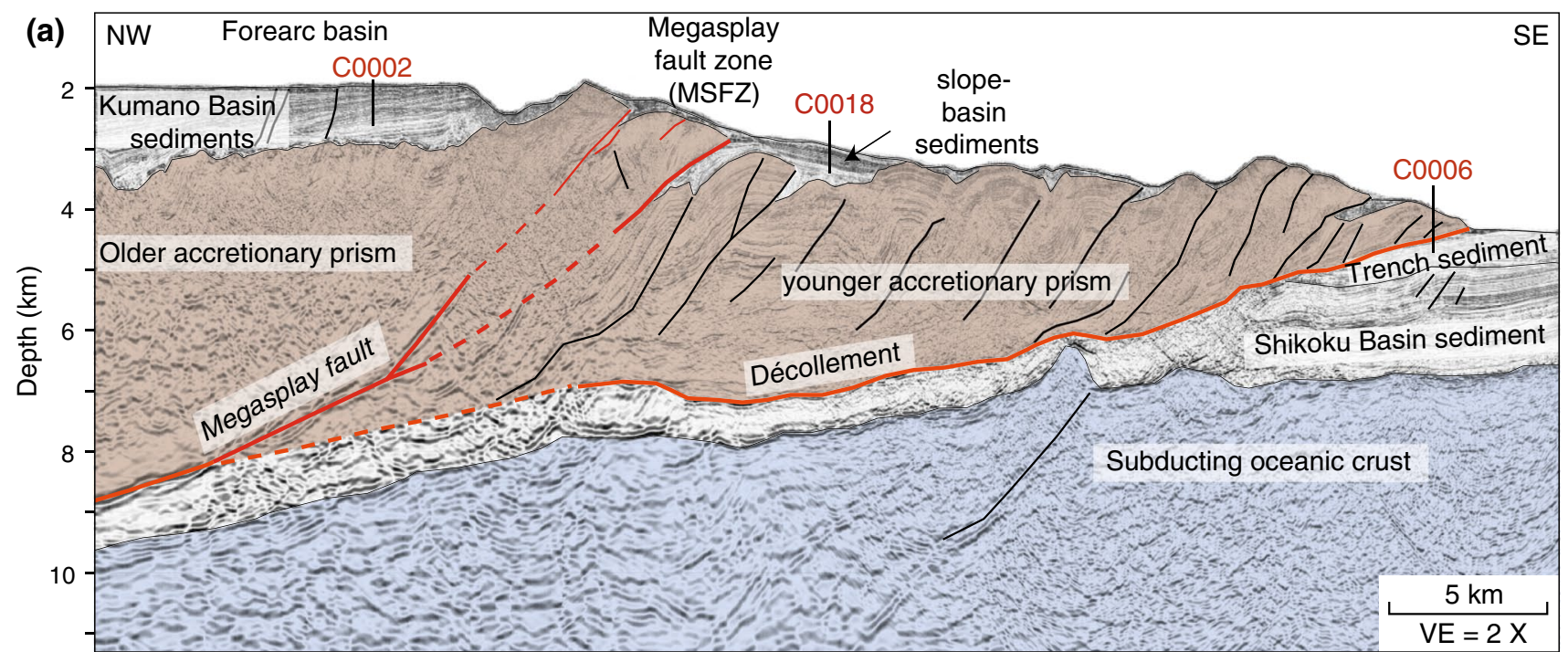

(b)

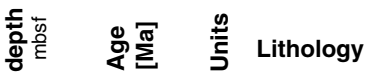

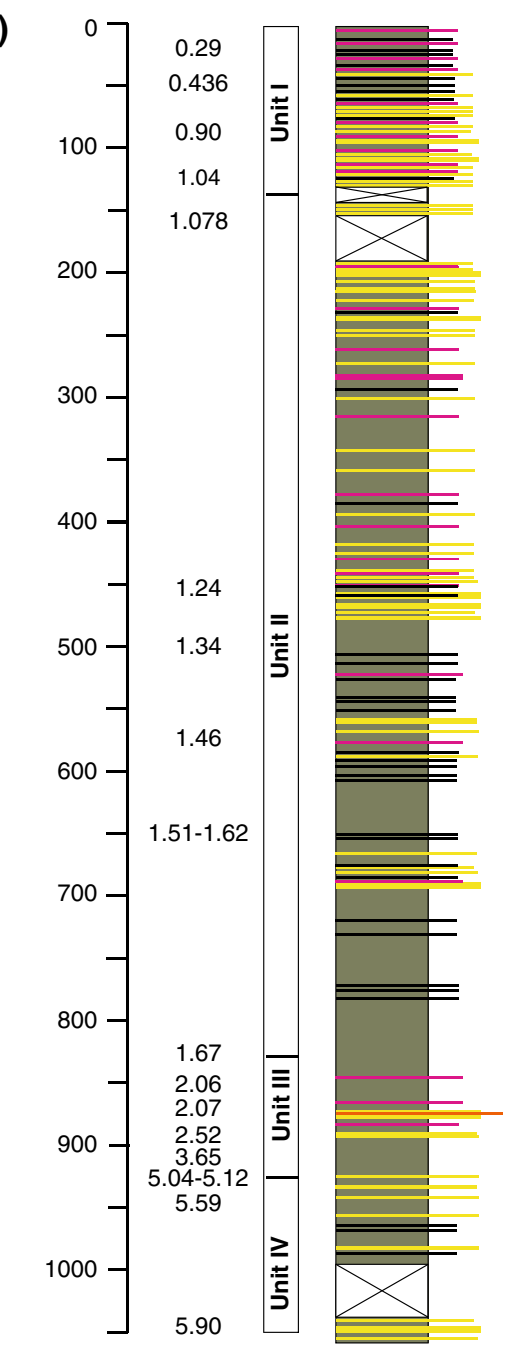

(c)
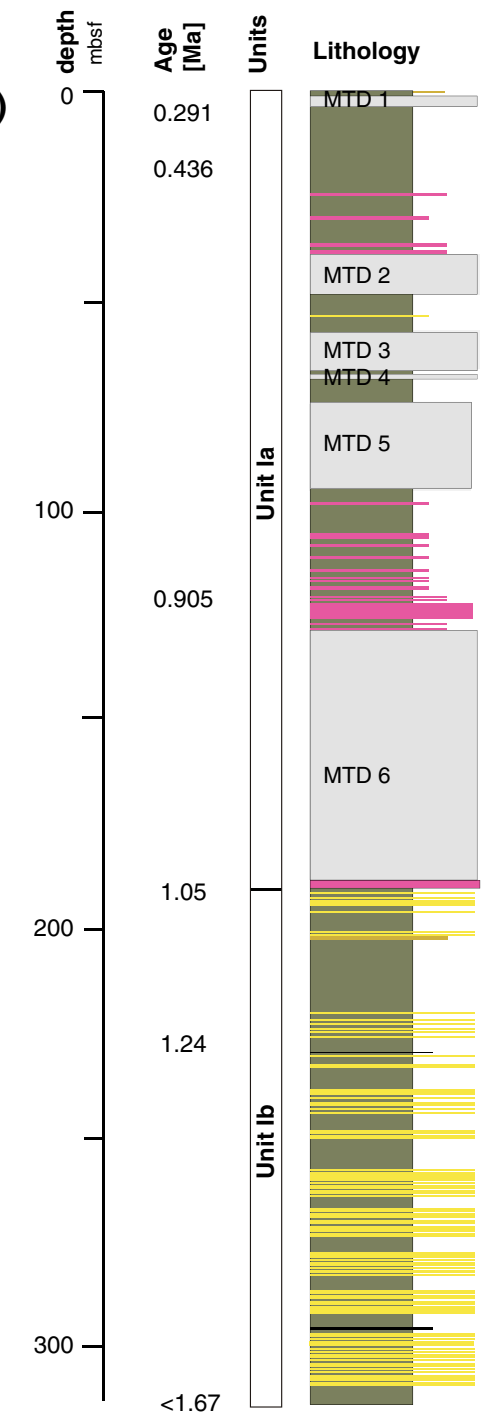

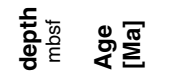

(d)

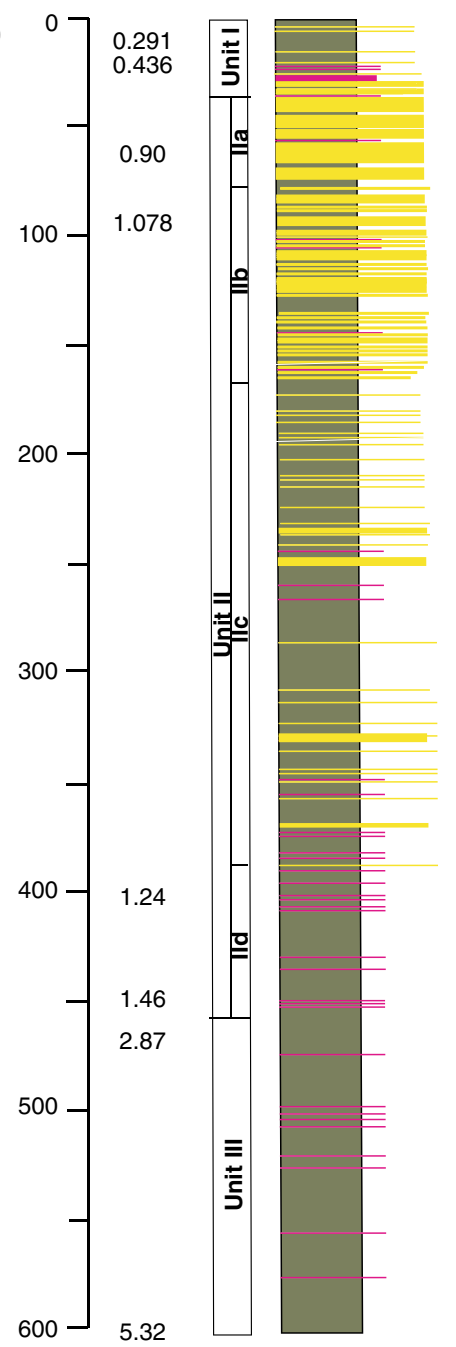

Hemipelagic mud

Turbiditic sands

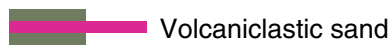

Silt turbidites 
dominated by hemipelagic settling, submarine landslides and minor contributions of volcanic ash. The lower Unit $\mathrm{Ib}$ consists of interbedded fine-grained to medium sand, silty sand, silty clay and clay. Silt and fine-grained silty clay and dark olive-grey sand are dominated by lithic fragments and feldspar. The proportion of lithic fragments decreases in very fine sand and silt layers. Some sand beds show normal grading with indistinct upper boundaries that grade into greenish, slightly bioturbated silty clay. This unit represents a sand-rich slope wedge system fed by siliciclastic and volcanogenic sources. The slope basin sediments are Quaternary $(<0.2 \mathrm{Ma}-\mathrm{ca}$. $1.67 \mathrm{Ma})$ in age, and the boundary between the upper and lower units corresponds to a time interval of $0.99-1.07 \mathrm{Ma}$ as obtained from tephrochronology and magnetostratigraphy (Fig. 2) (Expedition 333 Scientists 2012; Strasser et al. 2012).

\section{Trench-wedge facies (Site C0006)}

At Site C0006, which is located in the main frontal thrust zone at the seaward edge of the accretionary prism (Fig. 2), three lithologic units were recognized based on shipboard examination of core and $\log$ data. Unit I ( $0-27.23 \mathrm{mbsf})$ consists of a fining-upward succession of silty clay, sand, silty sand and rare volcanic ash layers deposited on the lowermost slope above the trench floor. These were deposited by hemipelagic settling and turbidite deposition that occurred after the frontal prism has been formed by accretion about $0.436 \mathrm{Ma}$ (Screaton et al. 2009). Unit II (27.23$449.67 \mathrm{mbsf}$ ) consists of four subunits and has been interpreted as having been deposited in a trench setting with increasing proximity to the axial part of the trench upslope before being accreted. Subunit IIa (27.23-72.06) is a dark grey to black fine-grained sand consisting dominantly of lithic fragments with secondary quartz and feldspar. Subunit IIb (72.06-163.33 mbsf) consists of interbedded finegrained sand, silty sand and silty clay in approximately equal abundances. Subunit IIc (163.33-391.33 mbsf) is dominantly greenish grey silty clay and minor normally graded silt, sand and rare volcanic ash. The dominant lithology in sub-unit IId (391.33-449.67 mbsf) is greenish grey silty clay, and minor lithologies include silt and ash. Sand is completely absent from this subunit, and ash layers are relatively abundant in comparison with the overlying units. An unconformity covering more than $1 \mathrm{Myr}$ was found between 434 and 439 mbsf. Unit III (449.67-603.00 mbsf) consists of greenish grey to greyish silty clay with some interbedded volcanic ash, including dolomite- and calcite-cemented ash. Units I and II are Pleistocene (ca. 0.42-1.46 Ma) in age, while Unit III is Late Miocene (ca 5.32 Ma) to Early Pleistocene in age (ca. 2.87 Ma). The Miocene-Early Pleistocene age and lithologic content of Unit III are similar to the Shikoku Basin facies documented at ODP Sites 1173 and 1174 in the Muroto transect by Underwood and Fergusson (2005) (Expedition 316 Scientists 2009a).

\section{Methods}

Representative sand and sandstone intervals from the three sites were sampled at the IODP core repository in Kochi, Japan. Additional volcanic ash layers in Unit Ia at Site C0018 were also sampled. Turbiditic sand layers were only found below the MTD 6. Loose and unconsolidated samples of approximately $40-60 \mathrm{~cm}^{3}$ were taken from two lithologic units each at all three sites. The samples were air-dried and then disaggregated and wet sieved in order to separate sand grains $(0.063-2 \mathrm{~mm})$ from finer materials. The very-fine- to fine-grained sand fraction (0.063$0.25 \mathrm{~mm}$ ) was selected and treated with acetic acid and hydrogen peroxide to eliminate carbonates and organic matter, respectively.

Two types of mounts were made for each sample: modal framework grain analysis thin sections and heavy mineral grain mounts.

For the modal framework grain analysis thin section, loose sands were impregnated with a bonding resin (araldite) and cut and polished for preparation of standard thin sections. The thin sections were etched with concentrated hydrofluoric acid and then stained with sodium cobaltinitrite, barium chloride and amaranth in order to distinguish calcium-bearing plagioclase from potassium-rich $\mathrm{K}$-feldspars following the detailed staining technique of Gabriel and Cox (1929) and refined by Houghton (1980). The modal framework grain analysis follows the procedures proposed by Dickinson (1970) and revised by Zuffa (1980).

Heavy minerals were concentrated from the dried sieved loose samples (grain size $=0.063-0.25 \mathrm{~mm}$ ) by methyl tribromide (density $=2.90 \mathrm{~g} / \mathrm{cm}^{3}$ ) following the procedures outlined in Mange and Maurer (1992). The loose heavy mineral grains $(0.8-2.2 \mathrm{~g})$ from the $0.063-0.25 \mathrm{~mm}$ fraction (7-40 g) were mounted on glass slides using piperine (refractive index $=1.68$ ). The heavy mineral distribution and concentration of each sample were then analysed using a petrographic microscope.

The bulk mineralogy of 80 thin sections was determined petrographically with a SWIFT automated stage mid-point counting system. For the bulk sand modal grain composition, the Gazzi-Dickinson point counting method (Dickinson 1970) was adopted because of its limited dependence on grain size. Approximately 200 and 300 points were counted in each sample for heavy mineral and modal sand composition, respectively.

In addition to the core samples, river sands were collected from seven representative rivers on the Pacific side 
of central to SW Japan as onshore references: Abe, Fuji, Kinokawa, Kiso, Kumano, Nagara and Tenryu Rivers. They were processed and analysed in the same manner as the core samples.

The potential of heavy mineral studies owes much to the great number of different species found in sediments (some 50 varieties of frequent occurrences; Mange and Maurer 1992). However, such numerous detrital species cannot be easily grouped into the few basic parameters that can be plotted in binary or ternary diagrams, as there is no established way to classify heavy minerals for this purpose (Garzanti and Andò 2007a). Nechaev and Isphording (1993) proposed a three end-member genetic classification based on some minor distinctions. For instance, they differentiated the brown, titanium-rich clinopyroxene from the green clinopyroxene and interpreted the former as products of ocean rifting and intraplate volcanism and the latter as suites derived from volcanic island arcs.

In this study, a different approach based on the Garzanti's ten key indices (Garzanti and Andò 2007a) was adopted in order to consider the full spectrum of minerals present in each sample and for easy division into supergroups with distinct provenance implications (see Section "Results").

\section{Results}

This study reports data from modal framework grain and heavy mineral analysis performed on 42 sand-sized samples (15 from Site C0002, 22 from Site C0018, and 5 from Site C0006 of the forearc basin, slope basin and trench environments, respectively). Results are presented in Table 1 and discussed below.

\section{Heavy mineral analysis}

The heavy mineral concentration, expressed as the volume percentage of the total heavy minerals in the bulk sample, provides the most fundamental evidence on provenance, hydraulic sorting or diagenetic processes. Therefore, the concentration of heavy minerals (and their spectrum) by itself is a crucial element that must be considered in provenance interpretations, especially while estimating sedimentary budgets from the integration of mineralogical and petrographic data as it primarily reflects the chemistry and tectonostratigraphic level of rocks eroded within continental block, arc or orogenic source terranes (Garzanti and Andò 2007b). Here, we report the heavy mineral concentration as well as the spectrum of the sand analysed in this study (Figs. 3, 4, 5, 6; Table 1). The ten indices, group based on similar provenance implications, are plotted in a ternary plot to indicate mineral suites derived from recycled orogenic materials of sedimentary and/or felsic igneous rocks, metamorphic and volcanic origin (Fig. 7).

The proportions of total zircon-tourmaline-rutile, hornblende and pyroxenes within the analysed sample vary with sites and units. The proportion of each mineral species from different lithologic units and sites are expressed as a percentage of the total mineral grains (Figs. 4, 5, 6). These indices are conventionally listed in the following order that mainly represent petrogenetic suites: ultrastable to relatively stable minerals, mainly derived from sedimentary and felsic igneous rocks (ZTR and T\&), minerals chiefly sourced from low-to-high-grade metamorphic rocks ( $\mathrm{LgM}, \mathrm{HgM}$ and $\mathrm{Gt}$ ) and minerals provided by intermediate, mafic, and ultramafic or metaigneous source rocks $(\mathrm{Hb}$, $\& A, C p x$, Opx and OS). These petrogenetic supergroups are then plotted in a conventional ternary diagram (Fig. 7).

\section{Heavy mineral concentration (HMC) index}

This defines the abundance of heavy minerals contained in the very fine to fine sand-size fraction of terrigenous extrabasinal loose sediment or lithified sedimentary rock and expresses the ability of a source rock unit to generate heavy minerals in the absence of significant chemical weathering, hydraulic sorting or diagenesis (Garzanti and Andò 2007a). We evaluated the HMC of the samples following the procedures and assumptions outlined by Garzanti and Andò (2007a). The HMC ranges from 4.9 to $16.2 \%$ with an average of $7.9 \%$ in the forearc basin sediments, from 4.7 to $22.7 \%$ with a mean of $9.5 \%$ in the slope basin sediments and from 6.5 to $15.3 \%$ with a mean of $9.4 \%$ for the trench-wedge sediments. These average values are similar to those reported for collision orogen $($ mean $=6.4 \%)$ and dissected magmatic arc of the alpine batholiths (14\%) by Garzanti and Andò (2007b). Generally, there is no clear and systematic trend (increasing or decreasing) in the HMC from top to bottom in all of the investigated samples.

\section{Zircon-tourmaline-rutile (ZTR) index}

This is an index that represents the combined percentage of ultra-stable minerals species (including rutile, tourmaline and zircon) among the transparent heavy minerals excluding micas and authigenic minerals. This is proposed as an index of the degree of the modification or "maturity" of the entire heavy mineral assemblages of sandstones (Hubert 1962). In the forearc basin section, ZTR in $\mathrm{C} 0002$ Unit I ranges from 13 to $23 \%$ with an average of $20 \%$. The older Unit II has a ZTR index range of 5-33\% and a $16 \%$ average. In Site C0018 Unit Ia, the ZTR ranges from 4 to $24 \%$ averaging $10 \%$ while the values in deeper and older Unit Ib range from 3 to $39 \%$ averaging $13 \%$. The trench-wedge deposit of C0006 has an average of 10 and $11 \%$ for the upper Unit 
Table 1 Modal abundance of heavy minerals in cores and reference river sands

\begin{tabular}{|c|c|c|c|c|c|c|c|c|c|c|c|c|c|c|c|c|}
\hline Sampl & HMC & $\mathrm{Zr}$ & Tml & $\mathrm{Rt}$ & $\mathrm{T} \&$ & LgM & $\mathrm{HgM}$ & Gt & $\mathrm{Hb}$ & $\& A$ & $\mathrm{Cpx}$ & Opx & OS & ZTR & $\mathrm{Mtm}$ & Vlc \\
\hline 0018A-4H-3 W, 83.0-88.0 cm & 12.4 & 13.5 & 1.2 & 0.6 & 0.6 & 1.8 & 0.0 & 1.2 & 24.0 & 0.0 & 6.4 & 50.9 & 0.0 & 15.2 & 2.3 & 82 \\
\hline$-5 \mathrm{H}-2 \mathrm{~W}, 34.5-41.0 \mathrm{~cm}$ & 6. & 1.2 & 3. & 4.2 & 3.6 & 8.4 & 0.0 & 1.2 & 61.4 & 0.6 & 1.8 & 13.9 & 0.6 & 8.4 & 12.0 & 78. \\
\hline C0018A-5H-3 W, $105.0-110.0 \mathrm{~cm}$ & 22.7 & 3.5 & 1.5 & 0.0 & 0.5 & 2.0 & 0.0 & 4.5 & 73.6 & 0.5 & 1.0 & 12.9 & 0.0 & 5.0 & 2.5 & 92. \\
\hline C0018A-6H-3 W, 19.0-24.0 cm & 5.6 & 4.1 & 1.4 & 1.4 & 0.9 & 4.5 & 0.5 & 2.3 & 32.6 & 0.0 & 1.8 & 50.7 & 0.0 & 6.8 & 5.9 & 87. \\
\hline C0018A-6H-3 W, 28.0-34.0 cm & 9.1 & 3.9 & 0.5 & 0.0 & 0.0 & 5.9 & 0.0 & 15.7 & 29.9 & 0.0 & 2.5 & 41.7 & 0.0 & 4.4 & 5.9 & 89. \\
\hline C0018A-6H-6 W, 67.0-72.0 cm & 18.2 & 9.3 & 0.0 & 3.6 & 0.5 & 7.3 & 1.6 & 1.6 & 56.5 & 1.6 & 6.7 & 11.4 & 0.0 & 13.0 & 9.3 & 77. \\
\hline 0018A-14H-7 W, 39.0-45.0 cm & 9. & 19.7 & 1.3 & 1.7 & 2.1 & 26.5 & 0.0 & 13.7 & 23.5 & 0.9 & 0.0 & 10.3 & 0.4 & 22.6 & 28.6 & 48. \\
\hline C0018A-14H-8 W, 88.0-93.0 cm & 6. & 1 & 1.9 & 0.0 & 1.9 & 3.8 & 0.0 & 1.3 & 45.3 & 0.0 & 12.6 & 32.1 & 0.0 & 3.1 & 5.7 & 91.2 \\
\hline $.5-28.5 \mathrm{~cm}$ & 14.9 & 3.9 & 2. & 1.7 & 1.7 & 10.1 & 0.0 & 4.5 & 38.8 & 0.6 & 0.0 & 36.0 & 0.0 & 8.4 & 11.8 & 79. \\
\hline 0018A-23H-2 W, 35.0-40.0 cm & 7.5 & 10.9 & 3.8 & 0.0 & 0.0 & 7.1 & 0.0 & 3.3 & 33.2 & 1.4 & 4.7 & 35.1 & 0.5 & 14.7 & 7.1 & 77. \\
\hline 0018A-28T-5 W, 31.0-36.0 cm & 8.5 & 6.8 & 3.4 & 0.0 & 0.8 & 24.6 & 0.0 & 18.9 & 34.8 & 7.2 & 0.4 & 2.7 & 0.4 & 10.2 & 25.4 & 64 \\
\hline 0018A-29T-3 W, 38.0-43.0 cm & 5.5 & 7.2 & 4.4 & 0.6 & 1.1 & 27.1 & 0.0 & .3 & 33.1 & 4.4 & 0.0 & 13.8 & 0.0 & 12.2 & 28.2 & 59. \\
\hline C0018A-30T-2 W, 60.8-65.8 cm & 8.4 & 4.9 & 4.9 & 0.8 & 0.4 & 14.2 & 0.0 & 3.3 & 48.4 & 19.5 & 0.4 & 3.3 & 0.0 & 10.6 & 14.6 & 74. \\
\hline C0018A-31X-2 W, $19.5-24.5 \mathrm{~cm}$ & 22.4 & 4.1 & 0.0 & 0.0 & 0.6 & 2.4 & 0.0 & 14.7 & 42.4 & 1.2 & 2.9 & 31.8 & 0.0 & 4.1 & 2.9 & 92.9 \\
\hline C0018A-31X-6 W, $122.0-127.0 \mathrm{~cm}$ & 7.0 & 11.9 & 3.5 & 0.5 & 0.0 & 15.3 & 0.5 & 35.1 & 26.2 & 4.0 & 1.0 & 2.0 & 0.0 & 15.8 & 15.8 & 68. \\
\hline C0018A-32X-3 W, $32.0-37.0 \mathrm{~cm}$ & 8.2 & 10.6 & 17.5 & 8.1 & 2.5 & 12.5 & 1.3 & 9.4 & 24.4 & 4.4 & 0.6 & 8.1 & 0.6 & 36.3 & 16.3 & 46. \\
\hline $0018 \mathrm{~A}-32 \mathrm{X}-5 \mathrm{~W}, 135.0-14.0 \mathrm{~cm}$ & 4.7 & 7.5 & 4.5 & 1.0 & 0.5 & 15.6 & 0.0 & 7.5 & 33.2 & 2.0 & 8.5 & 19.6 & 0.0 & 13.1 & 16.1 & 70. \\
\hline 0018A-33X-7 W, 69.0-74.0 cm & 4.5 & 9.1 & 1.2 & 0.8 & 0.4 & 14.6 & 0.0 & 21.7 & 47.6 & 1.2 & 0.4 & 3.1 & 0.0 & 11.0 & 15.0 & 14. \\
\hline$-82.0 \mathrm{~cm}$ & 5.8 & 1.8 & 1. & 0.0 & 0.0 & 32.7 & 0.0 & .8 & 53.2 & 1.2 & 0.0 & .2 & 0.0 & 2.9 & 32.7 & $64 . ?$ \\
\hline $\mathrm{cm}$ & 9 & 4 & 2 & 0.8 & 1. & 1 & 0 & 9 & 46 & 1.7 & .0 & 4 & 0.8 & 4 & 5 & 70. \\
\hline $8.0-143.0 \mathrm{~cm}$ & 7.0 & 6.0 & 4.5 & 0.0 & 1 & 1 & 0 & 8.5 & 36.3 & 0.0 & 1.0 & 9 & 0.0 & 10.4 & 18.9 & 70. \\
\hline $2 \mathrm{~W}, 30.0-35.0 \mathrm{~cm}$ & 4.8 & 3.0 & 12.6 & 0.0 & 0.0 & 35.7 & 0.0 & 3.0 & 32.2 & 2.0 & 0.5 & 11.1 & 0.0 & 15.6 & 35.7 & $48 .^{\circ}$ \\
\hline C0002D-5H-7 W, 96.0-101.0 cm & 16.2 & 0.5 & 1.0 & 23.8 & 0.0 & 24.9 & 0.0 & 0.5 & 24.4 & 0.0 & 7.8 & 14.0 & 3.1 & 25.4 & 24.9 & 46. \\
\hline C0002D-8H-7 W, $76.0-83.0 \mathrm{~cm}$ & 6.2 & 11.6 & 7.7 & 2.2 & 1.7 & 27.1 & 0.0 & 7.2 & 24.3 & 0.0 & 1.1 & 16.6 & 0.6 & 21.5 & 28.7 & 49.2 \\
\hline $\mathrm{C} 0002 \mathrm{D}-10 \mathrm{H}-8 \mathrm{~W}, 81.0-86.0 \mathrm{~cm}$ & 7.0 & 3.0 & 0.6 & 11.4 & 1.2 & 34.3 & 1.2 & 1.8 & 23.5 & 0.0 & 3.6 & 18.1 & 1.2 & 15.1 & 36.7 & 47. \\
\hline C0002D-11H-6 W, 70.0-75.0 cm & 6.0 & 12.4 & 3.6 & 8.2 & 2.1 & 1.5 & 0.0 & 7.7 & 52.6 & 0.0 & 2.6 & 7.2 & 2.1 & 24.2 & 3.6 & 70. \\
\hline $\mathrm{C} 0002 \mathrm{D}-13 \mathrm{H}-$ & 5.8 & 00 & 2 & 2.2 & 1.1 & 21.7 & 0. & 10.6 & 22 & 0.6 & 1.7 & 27.8 & 0.0 & 13.9 & 22.8 & 05 \\
\hline 000 & 6 & 1 & & & 9 & & 0 & & & & 4 & & 1.8 & & & 8. \\
\hline-100.0 C111 & 8.7 & 14.3 & 1.2 & 8. & 2.4 & & 0 & 7.7 & & & 0.0 & & 1.2 & & 6 & 49. \\
\hline $73.0-78.0 \mathrm{~cm}$ & 6.6 & 2.9 & 0.5 & 1. & 0.5 & 41.8 & 0. & 3.4 & 34.1 & 2.1 & 2.5 & 8.7 & 1.0 & 5.3 & 3 & 51. \\
\hline $0 \mathrm{~cm}$ & 8.9 & 10.0 & 4. & 1.8 & 1.4 & 30.9 & 1.4 & 4.5 & 29.5 & 0.0 & 1.4 & 14.1 & 0.5 & 16.4 & 33.6 & 49. \\
\hline C0002B-26R-1 W, $112.5-117.5 \mathrm{~cm}$ & 13.5 & 5.1 & 1.7 & 1.7 & 2.3 & 18.1 & 0.0 & 0.6 & 57.6 & 0.0 & 0.0 & 11.9 & 1.1 & 8.5 & 20.3 & 70. \\
\hline C0002K-5T-1 W, 49.0-54.0 cm & 6.3 & 25.8 & 4.2 & 3.3 & 3.3 & 10.8 & 0.0 & 25.8 & 13.8 & 0.0 & 4.6 & 7.5 & 0.8 & 33.3 & 14.2 & 51.7 \\
\hline C0002K-10X-7 W, 90.0-92.5 cm & 7.6 & 9.5 & 7.0 & 2.0 & 1.0 & 25.4 & 1.0 & 12.9 & 28.9 & 3.5 & 0.0 & 8.5 & 0.5 & 18.4 & 27.4 & 53 \\
\hline C0002L-09X-7 W, 79.5-83.0 cm & 4.9 & 6 & 5.4 & 1.4 & 2 & 30.6 & 0.0 & 12.2 & 29.7 & 0.9 & 1.4 & 9.5 & 0.5 & 13.1 & 32.9 & 53. \\
\hline $2.0-04.5 \mathrm{Cm}$ & 6. & 7. & 4 & 1 & 6 & 24 & 0 & 13.8 & 3 & 0.5 & 1.9 & 8.0 & 0.5 & 13.3 & 31.4 & 54 \\
\hline 0006E-4H-3 W, 133.0-138.0 cm & 6. & 3.4 & 5.8 & 1. & 0. & 28.2 & 0. & 1 & 35. & 0.0 & 0.0 & 24.3 & 5 & 10.2 & 28.6 & 60. \\
\hline 0006E-5H-5 W, 21.0-26.0 cm & 15.3 & 0.5 & 2.5 & 4.5 & 0.5 & 41.9 & 1.5 & 0. & 29.3 & 0.0 & 1.0 & 17.2 & 0.5 & 7.6 & 43.9 & 8. \\
\hline C0006E-8H-8 W, 65.0-70.0 cm & 8. & 6.1 & 2.5 & 3.6 & 3.0 & 0.0 & 1.5 & 2.0 & 45.2 & 0.0 & 2.0 & 28.4 & 0.0 & 12.2 & 10.2 & 7. \\
\hline $\mathrm{C} 0006$ & 7.5 & 8.6 & 1.9 & 2.9 & 0.0 & 43 & 1.4 & 21.9 & 42.9 & 0.0 & .5 & 15.7 & 0.0 & 13.3 & 5.7 & 8 \\
\hline Abe River & & 3.0 & 1.5 & 0.5 & 0.5 & 12.0 & 0.0 & 6.0 & 16.0 & 0.0 & 44.5 & 2.5 & 13.5 & 5.0 & 12.5 & 69. \\
\hline Fuji $R$ & & 3.4 & 0.0 & 0.0 & 1.3 & 13.9 & 0. & 3.4 & 19.7 & 0.0 & 40.3 & 17.4 & 0.3 & 3.4 & 15.5 & 80. \\
\hline Kinokawa $\mathrm{F}$ & & 0.0 & 0.0 & 1.0 & 1.5 & 64.0 & 0.0 & 3.0 & 28.5 & 0.0 & 0.0 & 1.0 & 1.0 & 1.0 & 65.5 & 32. \\
\hline Kiso River & & 9.1 & 0.0 & 0.0 & 1.0 & 2.9 & 2.9 & 0.0 & 29.8 & 0.0 & 20.7 & 33.6 & 0.0 & 9.1 & 6.8 & 84. \\
\hline Kumano River & & 38.0 & 1.0 & 2.5 & 0.0 & 25.0 & 0.5 & 18.0 & 10.0 & 0.0 & 2.0 & 3.0 & 0.0 & 41.5 & 25.5 & 33. \\
\hline Nagara River & & 4.0 & 0.0 & 1.0 & 0.5 & 1.0 & 0.0 & 4.0 & 1.0 & 0.0 & 22.8 & 65.7 & 0.0 & 5.0 & 1.5 & 93. \\
\hline Tenryu River & & 5.2 & 13.5 & 0.9 & 2.2 & 29.1 & 2.1 & 1.3 & 33.1 & 0.0 & 11.3 & 1.3 & 0.0 & 19.6 & 33.4 & \\
\hline
\end{tabular}

$H M C$ heavy mineral concentration, $Z r$ zircon, $T m l$ tourmaline, $R t$ rutile, $T \&$ titanium and others, $L g M$ low-grade metamorphic minerals, $H g M$ high-grade metamorphic minerals, $G t$ garnet, $H b$ hornblende (green + brown), \&A other amphiboles, $C p x$ clinopyroxene, $O p x$ orthopyroxene, $O S$ olivine + spinel, ZTR zircon-tourmaline-rutile $(\mathrm{Zr}+\mathrm{Tml}+\mathrm{Rt}), \mathrm{Mtm}$ metamorphic minerals $(\mathrm{T} \&+\mathrm{LgM}+\mathrm{HgM}), \mathrm{Vlc}$ volcanic minerals $(\mathrm{Gt}+\mathrm{Hb}+\& \mathrm{~A}+\mathrm{Cpx}+\mathrm{Opx}+\mathrm{OS})($ after Garzanti and Andò 2007a) 


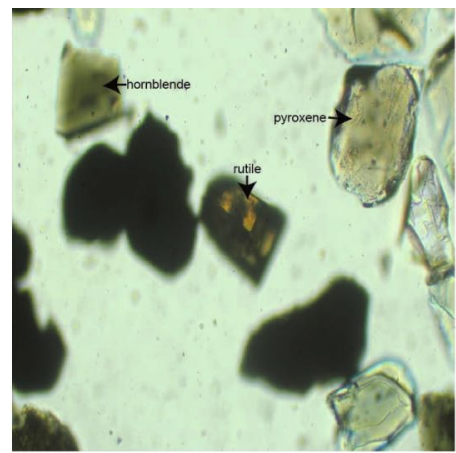

C0002D-10H-8W, 81-86 cm

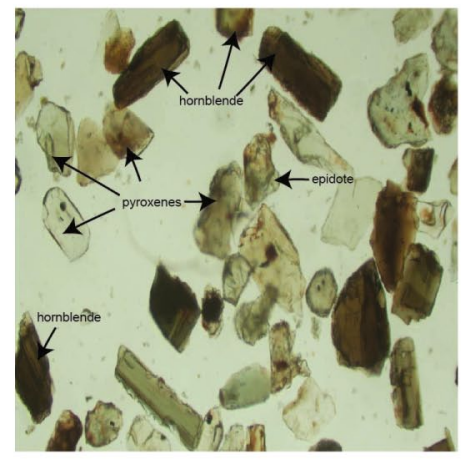

C0018A-15H-2W, 34.5-41 cm

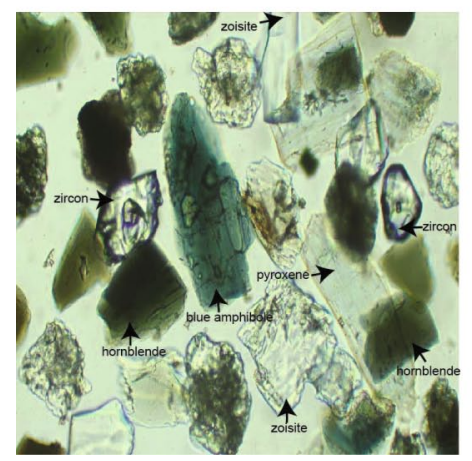

C0018A-33X-7W, 69-74 cm

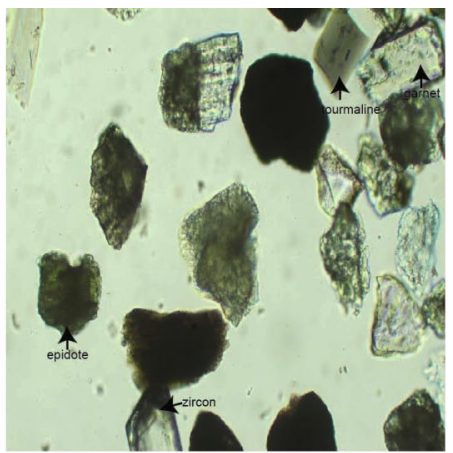

C0002D-14H-24W, 104-109 cm

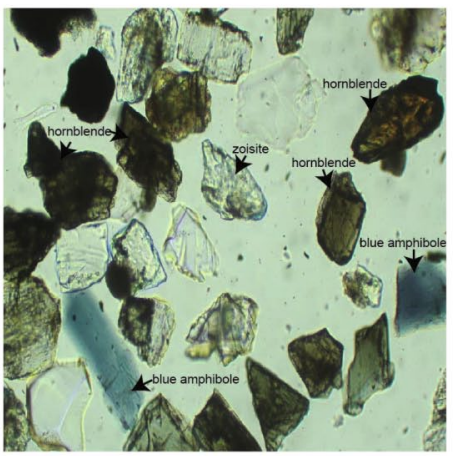

C0018A-30T-2W, $60.8-65.8 \mathrm{~cm}$

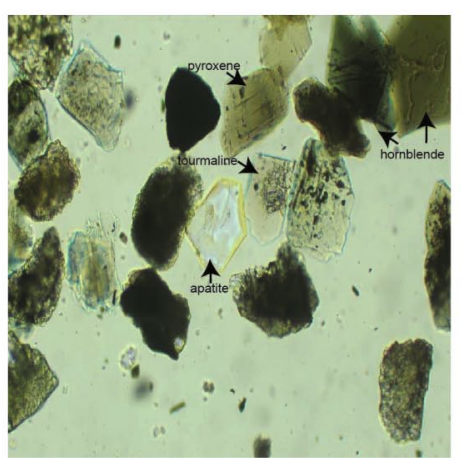

C0006E-4H-3W, 133-138 cm

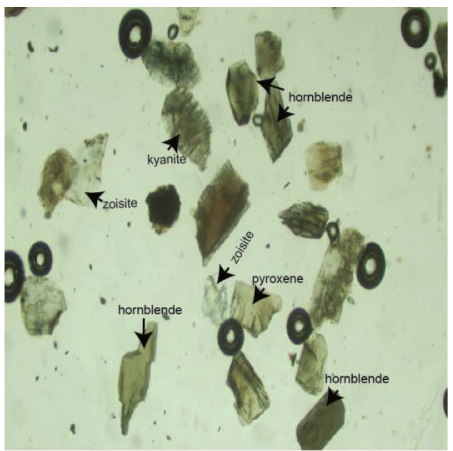

C0002B-26R-1W, $112.5-117.5 \mathrm{~cm}$

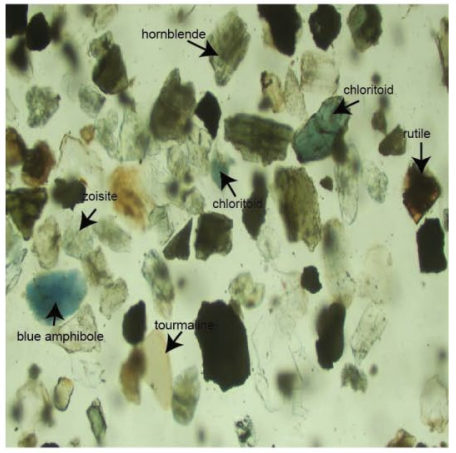

C0018A-36X-2W, 30-35 cm

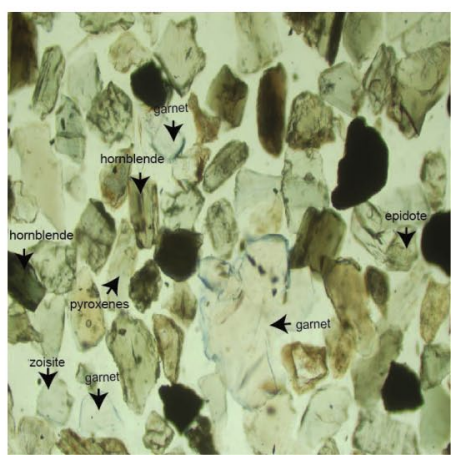

C0006E-11H-6W, 130-135 cm

Fig. 3 Photomicrographs of some selected samples showing the heavy mineral grains in each sample

I and lower unit II, respectively. The zircon and rutile grains are mostly at the initial to slight stage of corrosion, while the tourmaline grains are largely unweathered (Fig. 3; Andò et al. 2012). In general, the average ZTR index for the various sites is rather low, which presumably reflects inherent deficiency of the sources of the sands in zircon, tourmaline and rutile. The low values exclude repeated recycling of these ultrastable minerals from older sediments and therefore represent a primary provenance signal.

\section{Titanium minerals and others (T\&)}

This indicates the total percentage composition of titanium minerals (including sphene, anatase and brookite) and other transparent minerals (such as apatite) that cannot be classified into a specific group. The $T \&$ is, overall, very low and identical in all sites and units with C0002, C0018 and C0006 having an average of 3, 1 and $1 \%$, respectively, with no discernable trends. The apatite grains are either unweathered or at the initial stage of corrosion (Fig. 3; Andò et al. 2012).

\section{Low-grade metamorphic minerals ( $L g M)$}

This expresses the percentage composition of heavy mineral suites of the epidote group (including epidote, clinozoisite, zoisite and piemontite) and chloritoid, among the total heavy mineral assemblage. This classification is a first-order 


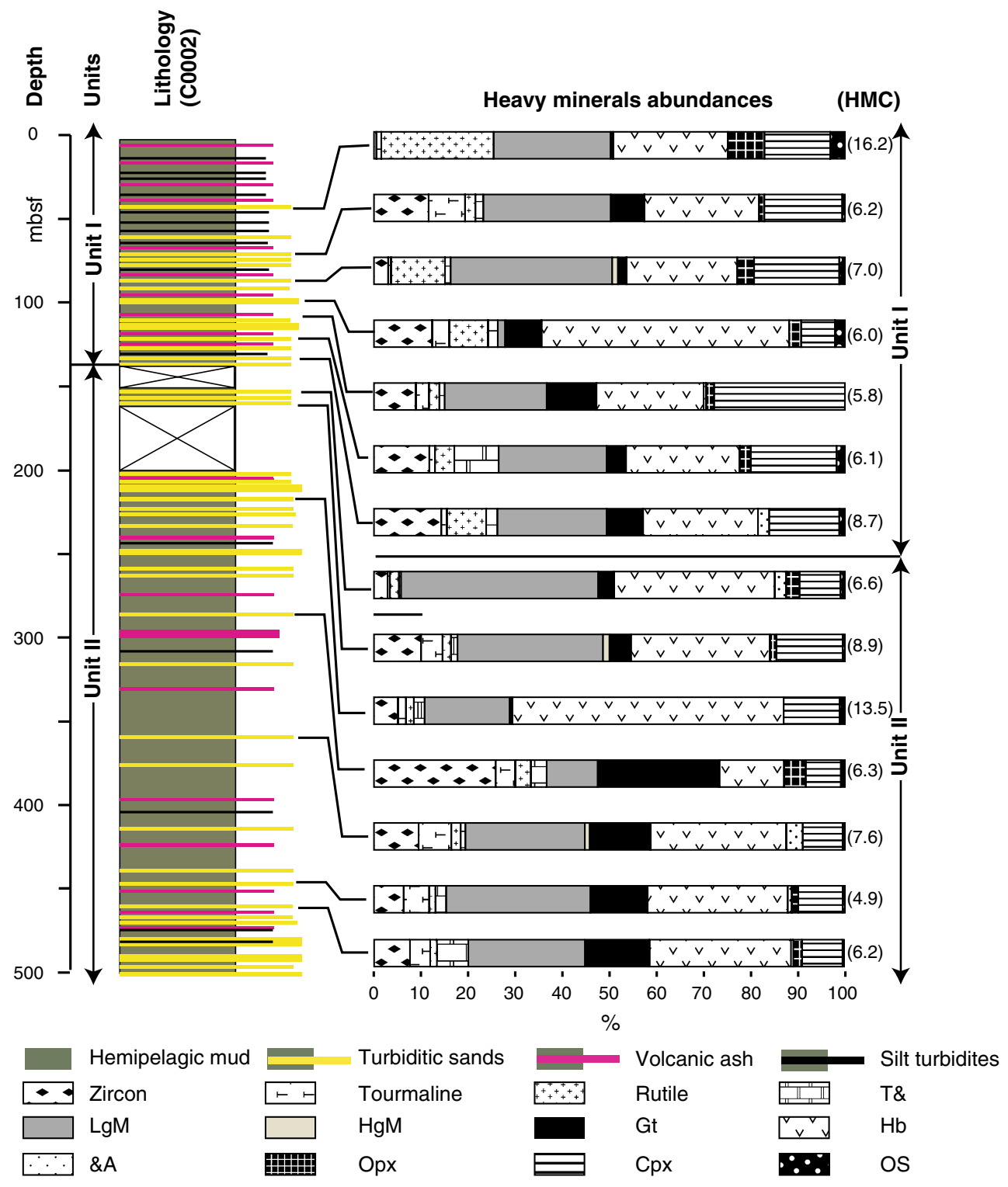

Fig. 4 Heavy mineral distribution and concentration in the sand layers at Site C0002. Abbreviations used in figure and legend are as follow: $H M C$ heavy mineral concentration; $T \&$ titanium and others; $L g M$ low-grade metamorphic minerals, $H g M$ high-grade meta- morphic minerals, Gt garnet; $H b$ hornblende (green + brown); \&A other amphiboles; $C p x$ clinopyroxene; $O p x$ orthopyroxene; $O S$ olivine + spinel (after Garzanti and Andò 2007a)

a drastic change in the $\mathrm{LgM}$ composition in the slope basin from an average of $19 \%$ in Unit Ib to less than $8 \%$ in Unit Ia. A noteworthy observation is the remarkable similarity in the heavy mineral suites of Unit II and Unit Ib of Sites C0002 and C0018, respectively. The trench wedge is comparable to both Unit II and Unit Ib of the forearc and slope basin, respectively, with an average of $20 \% \mathrm{LgM}$ composition. The grains of the epidote group minerals (including epidote, zoisite and clinozoisite) are at the initial to slight stage of corrosion, while the chloritoid grains are unweathered. The sodic amphiboles are mostly unweathered to etched and slightly corroded (Fig. 3; Andò et al. 2012). 
Fig. 5 Heavy mineral distribution and concentration in the sand layers at Site C0018. For symbols, see legend in Fig. 4

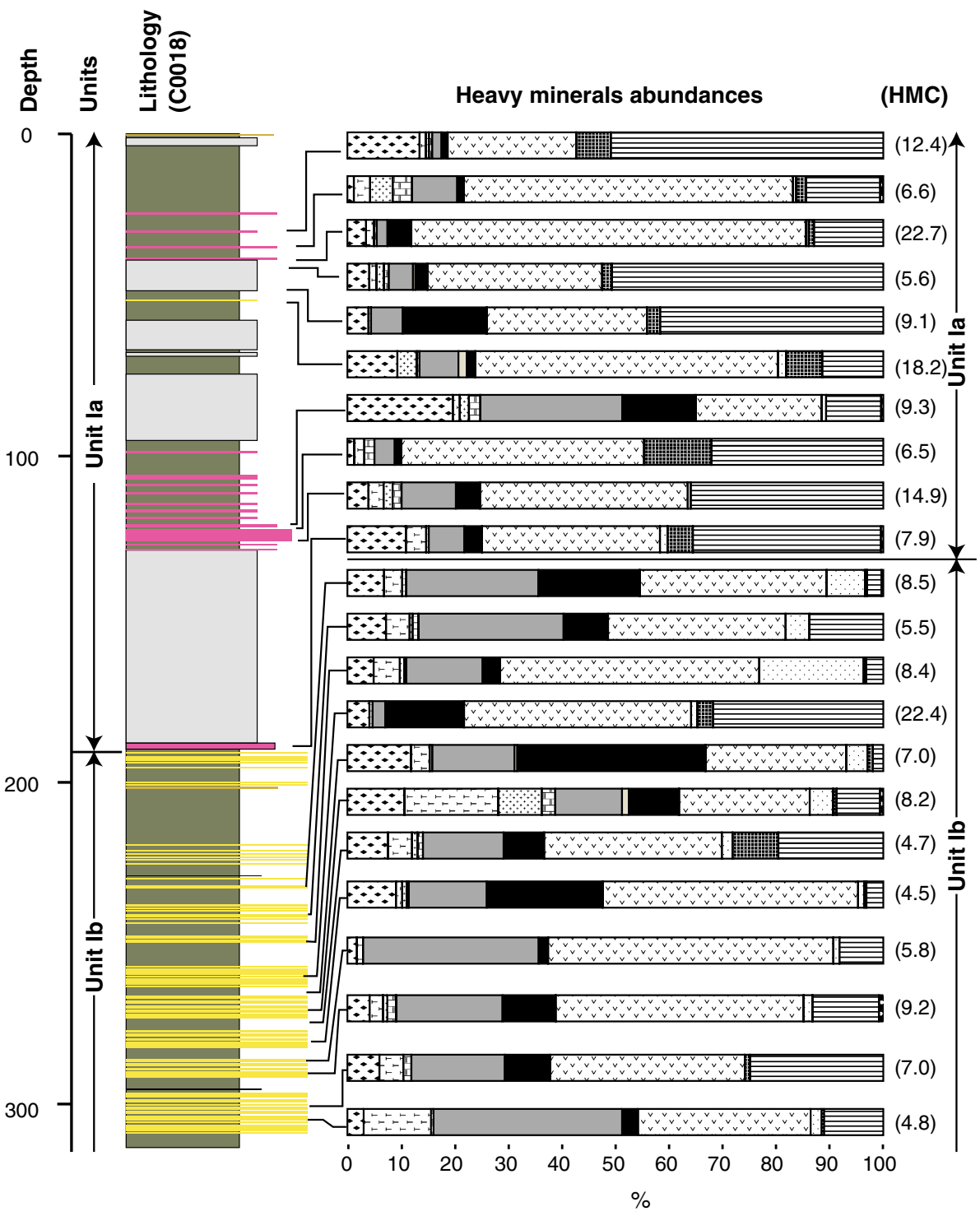

\section{High-grade metamorphic minerals (HgM)}

This represents the combined percentage of heavy mineral species chiefly derived from high-grade amphibolite facies metaigneous and metasedimentary rocks. This includes minerals such as staurolite, andalusite, kyanite and sillimanite. The $\mathrm{HgM}$ is generally very low in all sites and units ranging from $0.2 \%$ in $\mathrm{C} 0002$ Unit I and C0018 Unit Ib to $1.5 \%$ in Site C0006. Staurolite grains are slightly corroded and etched while kyanite grains are mostly at the initial stage of corrosion (Fig. 3; Andò et al. 2012).

\section{Garnet $(G t)$}

This represents the combined percentage of garnet present in the analysed sample. Garnet is usually found in metamorphic rocks but can be present in plutonic and ultramafic igneous rocks. It is usually found in metapelites and metabasites, and it is commonly derived from contact metamorphism of impure limestone, metasomatic skarns and schists that were produced by regional metamorphism of limestone (Mange and Maurer 1992). Garnet is one of the most ubiquitous mineral species as it is found in all of the samples investigated albeit to a varying degree in sites and units. At Site C0002, the average is $6 \%$ and $11 \%$ for Units I and II, respectively. At Site C0018 Unit Ia, the composition ranges from 1 to $15 \%$ averaging $5 \%$, and $2-35 \%$ in Unit Ib with an average of $12 \%$. The trench sediment ranges from $2 \%$ in Unit I to $8 \%$ in Unit II. The garnet grains are mostly unweathered with few grains at the initial stage of corrosion (Fig. 3; Andò et al. 2012).

\section{Hornblende $(\mathrm{Hb})$}

This indicates the overall percentage of the widely abundant calcic amphibole (including the green and brown variety of hornblende) among the total heavy mineral species. 
Fig. 6 Heavy mineral distribution and concentration in the sand layers at Site C0006 (a) and reference river sands (b). For symbols, see legend in Fig. 4

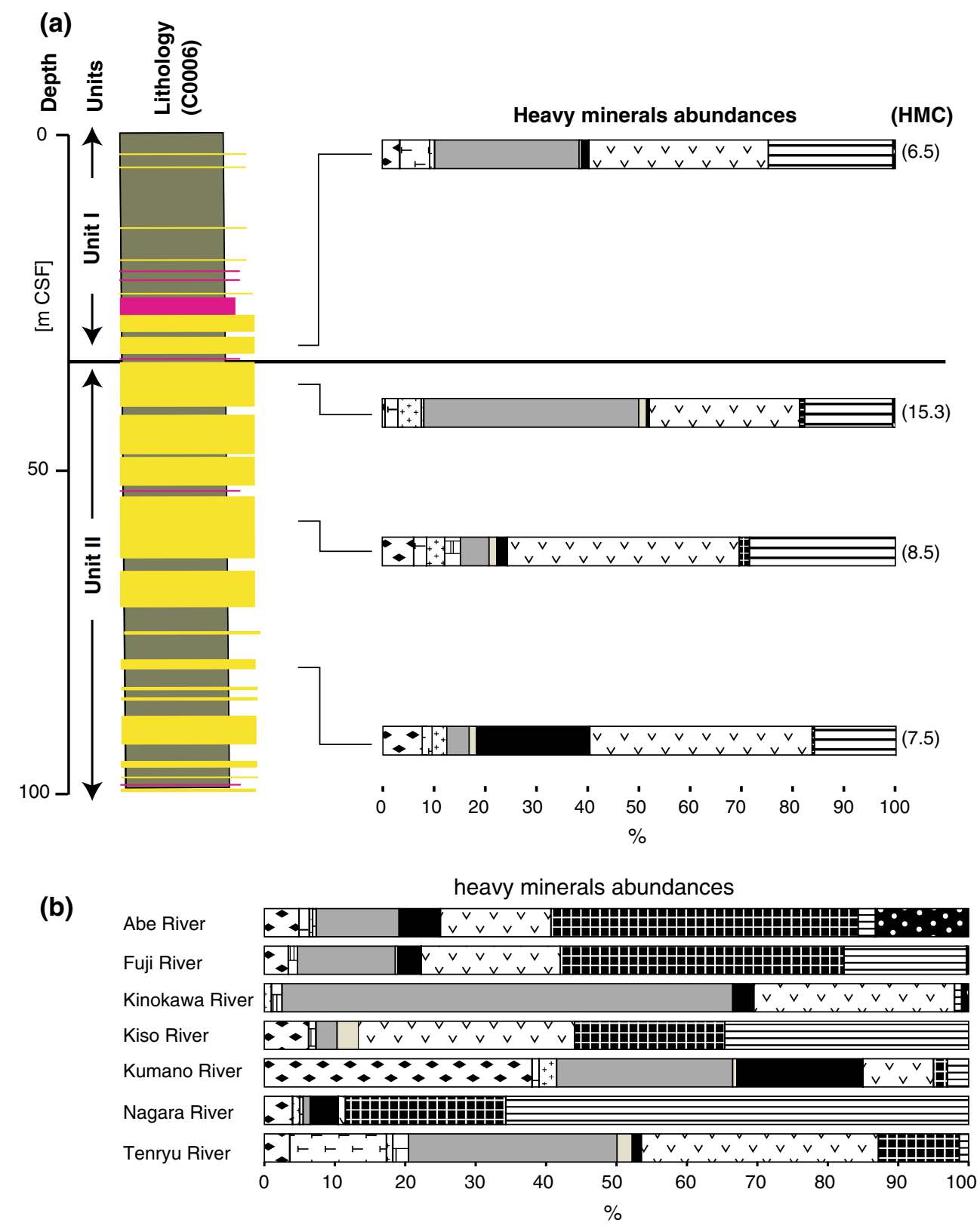

(b)
Hornblende is unarguably the most common mineral in all investigated samples. At $\mathrm{C0002}$ and $\mathrm{C0006}$, the average composition of hornblende reduces from bottom to top of the lithostratigraphic column. On the other hand, the hornblende composition increases from bottom to top at $\mathrm{C} 0018$ from 37 to $42 \%$. The lowest hornblende composition is observed in Unit I of C0002 with an average of $27 \%$. The degree of corrosion in the hornblende grains ranges from unweathered to slight, whereas the weathering stage ranges from unweathered to corroded (Fig. 3; Andò et al. 2012).

\section{Other amphiboles (\&A)}

This represents the combined percentage composition of all other amphiboles (including tremolite and actinolite) among the heavy mineral species. Generally, the composition of \&A is negligible, $<4 \%$, in all sites and units. \&A is totally absent in the trench-wedge deposits. \&A ranges from 0.5 in both Unit I and Unit Ia to $4 \%$ in Unit II and Unit Ib of $\mathrm{C} 0002$ and $\mathrm{C} 0018$, respectively. The few tremolite grains observed are unweathered.

\section{Clinopyroxene (Cpx)}

This is the combined percentage composition of augite and diopside among the heavy mineral species in the analysed specimen. In general, all the sites and units are deficient in clinopyroxene with $<4 \%$ in all samples. There is an overall subtle increase in the clinopyroxene content from bottom to top in all sites. The augite and diopside grains are mostly at 


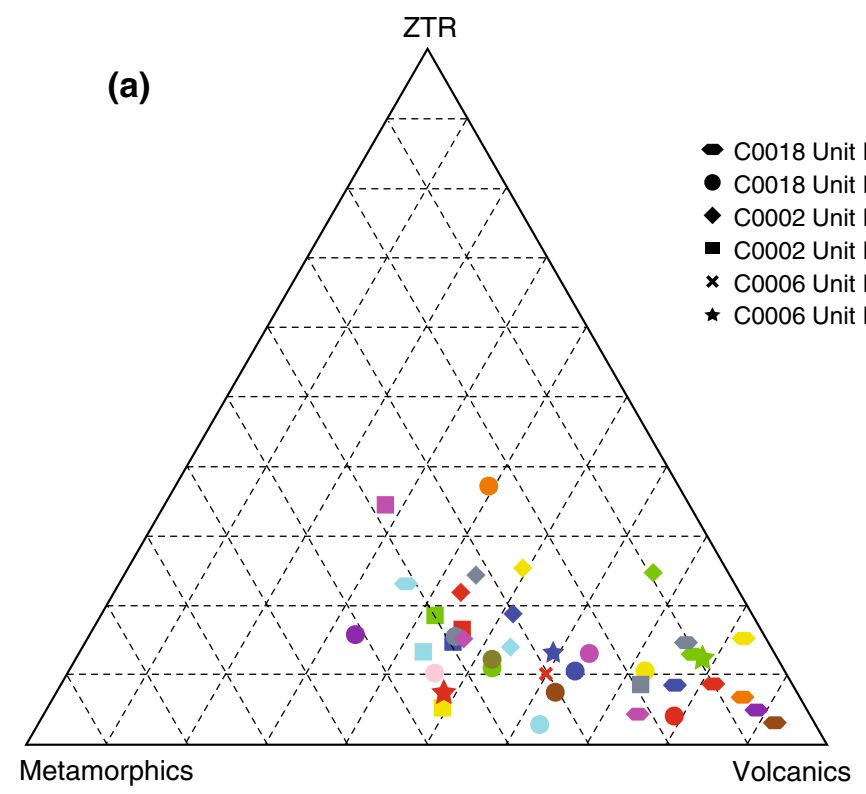

Fig. 7 Ternary plot of the modal proportion of heavy minerals in cores (a) and river sand samples (b). Notes on figure: the colour bar indicates the depths in the stratigraphic section from top (shallow) to bottom (deep). For example, a yellow hexagon is shallower

the initial stage of corrosion and are slightly etched (Fig. 3; Andò et al. 2012).

\section{Orthopyroxene (Opx)}

This represents the combined percentage of hypersthene and enstatite in the heavy mineral suite. In contrast to the clinopyroxene, the orthopyroxenes are widely distributed and relatively abundant in most of the analysed samples. Hypersthene accounts for most of the orthopyroxene ( $>94 \%)$ as few grains of enstatite are present in a few number of the analysed samples. The general observed trend is an increase from bottom to top of the stratigraphic column in all sites. Compared with the other two sites, $\mathrm{C} 0002$ has very low orthopyroxene content ranging from 10 to $16 \%$. Unit Ia of $\mathrm{C} 0018$ contains the highest proportion of orthopyroxene with an average of $30 \%$. Most of the observed orthopyroxene (mostly hypersthene) are unweathered or at the initial stage of corrosion (Fig. 3; Andò et al. 2012).

\section{Olivine and spinel (OS)}

This expresses the total percentage of olivine and spinel present in the samples. The olivine and spinel composition in all the units and sites is negligible having as low as $0.4-1.5 \%$ in all samples. There is no discernable systematic trend in compositional variations in olivine and spinel in all the sites and units. The few grains of spinel observed are slightly corroded

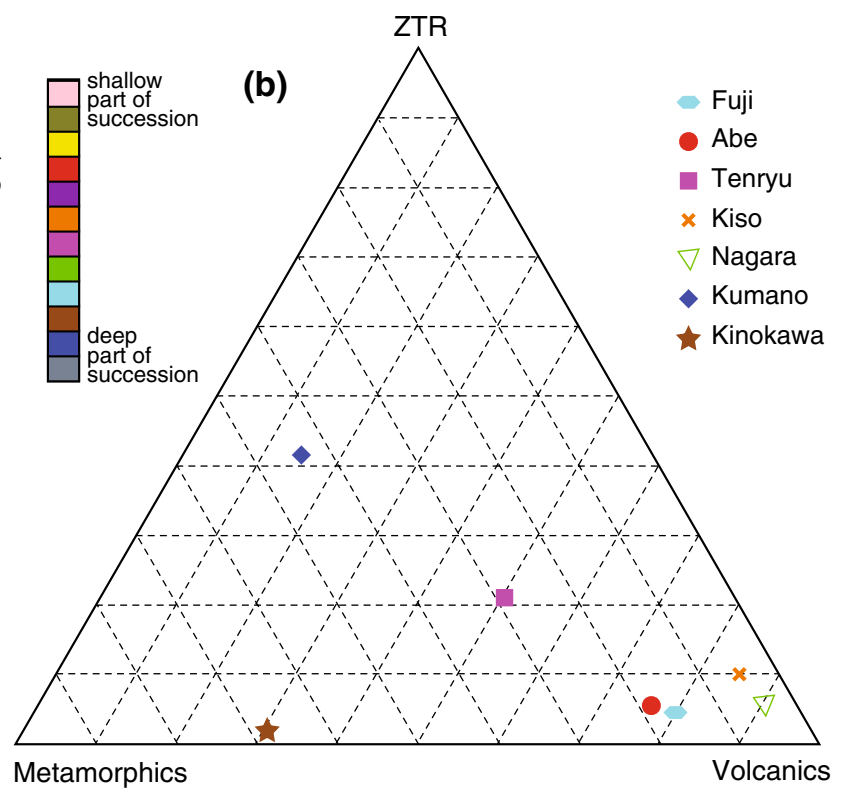

than a blue hexagon, although they belong to the same Unit Ia of Site $\mathrm{C} 0018$, and a brown diamond is deeper than a red diamond, despite that they belong to the same Unit I of Site C0002

\section{Reference rivers}

The river samples also have characteristic heavy mineral modal proportions (Table 1; Figs. 6, 7). Samples of the Fuji, Abe, Kiso and Nagara Rivers bear significant amount of pyroxenes. The pyroxene minerals in Kiso and Nagara are mostly euhedral in shape, suggestive of tephra origin. Abe River comprises spinel as a dominant component, which is absent in other river samples with the exception of the Kinokawa River, where a few grains were found. The Kinokawa River runs in the central Kii Peninsula to the west along the Median Tectonic Line and has more tributaries in its southern side, where the Sanbagawa metamorphic belt (including the Mikabu Greenstones) and the Shimanto accretionary complex are located (Fig. 1). The Kumano River sample shows high abundance in zircon, and sometimes garnet is common. The Tenryu River has the greatest diversity in heavy mineral composition among analysed river samples. It contains pyroxene, hornblende, epidote group minerals and tourmaline in moderate ratio as well as a variety of other minor components such as zircon, garnet, allanite and actinolite.

\section{Modal framework grain composition}

The sand samples recovered from the forearc basin, slope basin and trench wedge are divided into three major petrofacies as defined by Folk (1968). These petrofacies are as follows: feldspathic litharenites (C0002, C0006 and 

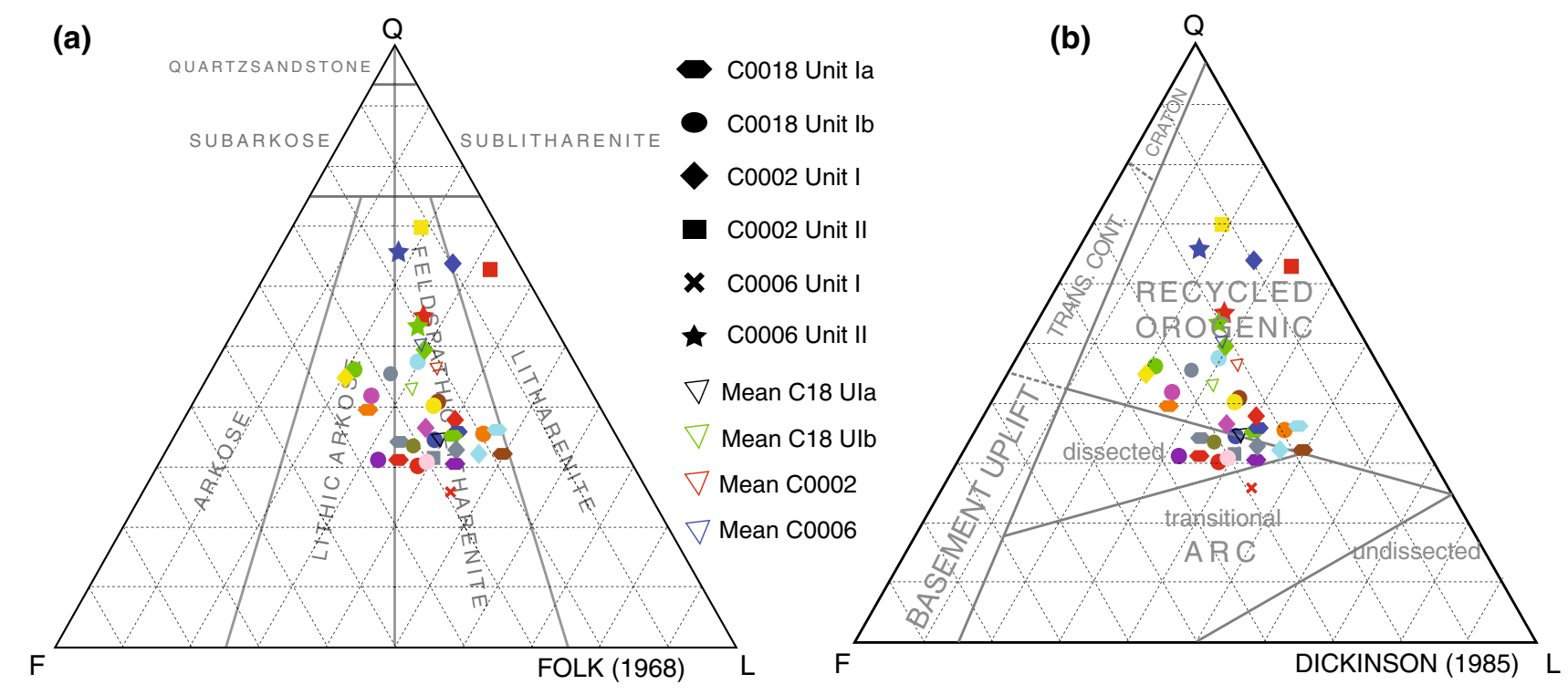

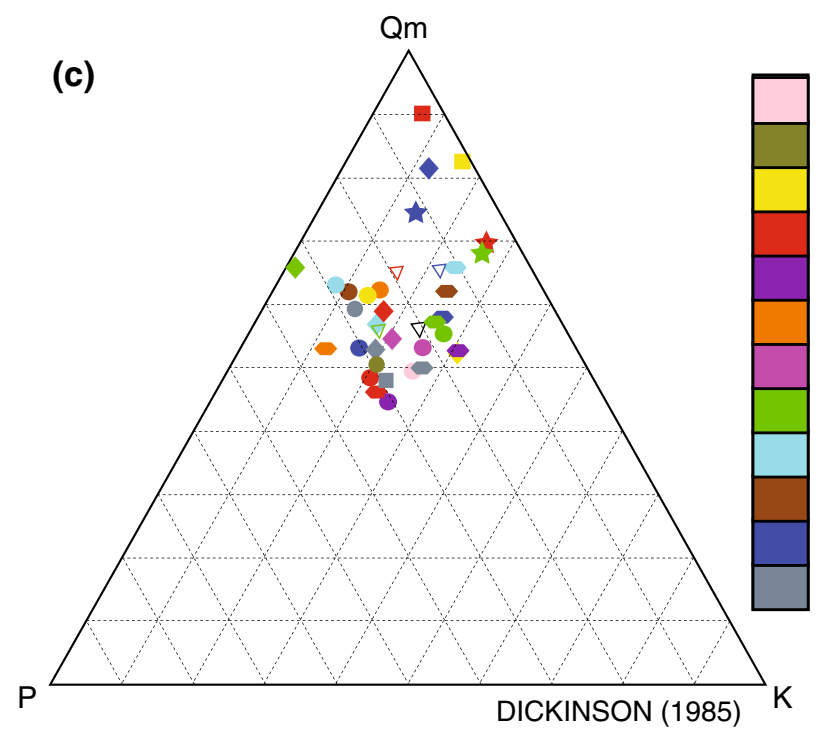

Fig. 8 Detrital modal plots for the Nankai Forearc sands. a, b Q-FL, c Qm-P-K, d Lvh-Ls-Lm. Q = Total quartz (monocrystalline quartz and polycrystalline quartz), $Q m$ quartz monocrystalline, $P$ Plagioclase, $K \mathrm{~K}$-feldspar, $F$ Feldspar $(\mathrm{P}+\mathrm{K}), L$ lithic fragment, $L t$ total

C0018), lithic arkose (C0002 and C0018) and litharenite (C0002) (Fig. 8a).

The sands from the Pliocene forearc basin facies sampled at the Kumano Basin Site C0002 are medium-grained to coarse-grained and subrounded to subangular. Sample depths at the site range from 42.39 to $704.625 \mathrm{mbsf}$. The most characteristic constituents of this deposit are quartz and volcanic lithic fragments. On the Q-F-L plot, the mean field for Site C0002 Unit II lies close the quartz-lithic corner (Fig. 8b). The mean modal values are Q-46 \%, F-20\%, L-34 \% (the \% will subsequently be omitted), and Lvh- 40 , Ls-25, Lm-35, but there is a significant scatter about the

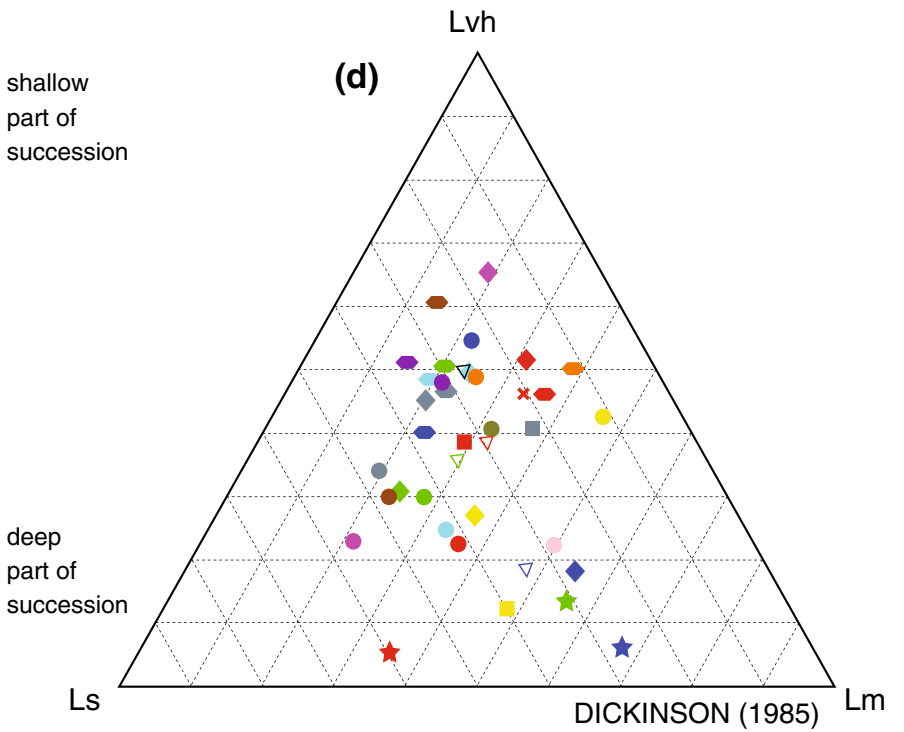

lithics, $L v h$ volcanic lithics, $L s$ sedimentary lithics and $L m$ metamorphic lithics. Notes: see Fig. 7 for colour scheme. The triangle symbols indicate the mean modes of each site as appropriate

mean (Fig. 8b-d). The average Qm-P-K modes are Qm65, P-19, K-16 (Fig. 8c). The detrital modes are considerably similar to the $\mathrm{C} 0018 \mathrm{Unit} \mathrm{Ib}$ modes, and the most evident distinction is in their monocrystalline components. The monocrystalline quartz in $\mathrm{C} 0002$ goes as high as $65 \%$, while the plagioclase and $\mathrm{K}$-feldspar contents are considerably similar to those of C0018 Unit II.

Samples from very fine-grained sand layers in the upper, Middle to Late Quaternary stratigraphic interval (Unit Ia) at the slope basin Site $\mathrm{C} 0018$ are from depths ranging from 29.48 to $189.185 \mathrm{mbsf}$. The sands are dominated by volcaniclastic materials probably derived from the Honshu 
and Shikoku Arcs. Their modes plot near the L section on a quartz-feldspar-lithic (Q-F-L) diagram with a mean of Q-34, F-26, L-40, and close to the Lvh corner on the volcanic-sedimentary-metamorphic lithic (Lvh-Ls-Lm) plot with a mean Lvh-Ls-Lm of Lvh-53, Ls-22 and Lm-25 (Fig. 8b-d). Feldspar is the most abundant monocrystalline component, and K-feldspar dominates. The mean Qm-P-K modes are Qm-36, P-30, K-34 (Fig. 8c). The volcanic fragments are characterized by feldspar and quartz phenocrysts with minor devitrification textures. Within the layers, there are numerous fine-grained sedimentary and metamorphic lithic fragments, although in some of the grains, distinction between chert and sedimentary lithic fragment is difficult. Few grains of volcanic glass were also identified.

The lower stratigraphic section (Unit Ib) of C0018 is characterized by medium-to-coarse-grained sands belonging to the Early Pleistocene slope basin facies. In comparison with Unit Ia, it is extremely rich in sandy intervals and sample depths range from 233.185 to 305.22 mbsf. The grains are dominantly angular to subangular and contain abundant quartz and volcanic rock fragments. Plagioclase is the dominant feldspar type. The mean modal values for the 12 samples recovered from this unit are Q-38, F-28, L-34, and Lvh-38, Ls-30, Lm-32. The average Qm-P-K modes are Qm-56, P-26, K-18 (Fig. 8b-d). A large number of the monocrystalline quartz grains display undulose extinction with incipient polygonal shape with no visible deformation band. This suggests a low-grade metamorphic source rock for the sand. Many of the fine-grained rock fragments are volcanic glass and/or fine-grained mudstone and minor quantities of phyllosilicate grains.

Site C0006, drilled near the seaward edge of the accretionary prism, provides a great constraint on the trenchwedge sedimentation. Here, only four samples were investigated for modal analysis. The total quartz content for the sands is as high as $50 \%$, while the remainder is made up of lithic fragments. Metamorphic lithic fragments account for over $50 \%$ of the total lithic fragments with 30 and $20 \%$ of sedimentary and volcanic lithic fragments, respectively (Fig. 8b). Sample depths range from 28.365 to 70.204 mbsf. The mean modal values are Q-50, F-21, L-29 (Fig. 8b), and Lvh-20, Ls-29, Lm-51 (Fig. 8d). Some of the monocrystalline quartz grains are similar to those from $\mathrm{C} 0018$ Unit Ib in that the grains show undulose extinction, developed polygonal shapes and rare deformation bands. Few grains of fine-grained quartz and lithic sandstone are also present.

\section{Discussion}

There are fundamental spatial and temporal variations in the bulk composition of the Kumano Basin, slope basin and trench-wedge sediments of the Nankai Trough. In the western portion of the Nankai accretionary wedge, trenchslope basin sediments on the lower slope were derived from Cretaceous-Tertiary Shimanto metamorphic and NeogeneQuaternary volcanic rock exposed along the southwestern margin of the Japan Island Arc (Marsaglia et al. 1992). Several rivers along the southeastern margins of Shikoku, Kyushu and Honshu crosscut the Shimanto complex and drain into several submarine canyons and forearc basin along the Nankai Trough (Fig. 1). At present, only a few of these submarine canyons are directly linked to the Nankai Trough (e.g. Suruga Canyon; De Rosa et al. 1986). Taira and Niitsuma (1986) found a close correlation between the Suruga Trough and Fuji River and concluded that the Suruga Trough is fed by the Fuji River. Quaternary sands from the lower sandy unit in Site C0018 suggest a mixed provenance: recycled orogen and dissected magmatic arc (Fig. 8). This implies that the Cretaceous-Tertiary Shimanto Belt may have been the major source of sands in Unit $\mathrm{Ib}$ at C0018. Shimanto Belt sedimentary sequences, which have been deformed by strike-slip faulting, folding and compression, vary from unmetamorphosed to weakly metamorphosed rocks (Taira et al. 1982). Therefore, subaerial/ submarine erosion of fine-grained units within the Shimanto Belt could have produced the sedimentary and metamorphic lithics found in the Mid-Quaternary turbidite succession of the offshore slope basin (Fig. 8b). However, the relatively high percentage of volcanic lithics in the upper Late Quaternary Unit Ia sands (Fig. 8b) suggests additional volcanic sources to the trench-slope basin after $\sim 1 \mathrm{Ma}$. The dominantly microcrystalline volcanic lithics assemblage in Unit Ia could have been derived from volcanic centres in the Fuji region of central Honshu. The Q-F-L modes plot on Dickinson's (1985) recycled orogen and dissected arc field, and this bimodal provenance may be characteristic of marginal basins formed by rifting of continental-margin arc systems (Marsaglia et al. 1992).

There are also clear and systematic differences in heavy mineral composition by sites and lithologic units. Both forearc and slope basin sands from the upper units (I and Ia, respectively) are differentiated from the deeper units (II and $\mathrm{Ib}$ at Sites C0002 and C0018, respectively) by increased abundances of pyroxenes and the green and brown varieties of hornblende. This distinction is most evident in the slope basin facies where the volcanic minerals-pyroxene and green/brown hornblende-increase from half of the heavy mineral component in Unit Ib to over $75 \%$ of total heavy mineral species in Unit Ia. This transition is more subtle in the forearc basin facies, with a modest $4 \%$ increase from $45 \%$ in Unit II to $49 \%$ in Unit I. The observed changes in heavy mineral composition could result from changes in provenance of the detrital grains, hydraulic sorting effect and selective dissolution of unstable heavy minerals 
resulting from surficial weathering in the basin and/or during burial diagenesis. The surficial textures of all analysed grains range from unweathered to slightly corroded (Fig. 3), showing that dissolution of unstable heavy minerals is a minor and relatively negligible factor for such a drastic and significant change in heavy mineral composition. Also, pore-water geochemical analysis of dissolved species at Sites C0006 and C0018, which may indicate alteration of mineral species, shows little or no alteration (Expedition 316 Scientists 2009a; Expedition 333 Scientists 2012; Expedition 338 Scientists 2013). At site C0002, there is some evidence from pore-water geochemistry for clay mineral reactions and cycling of iron/manganese in the deepest part (Expedition 314 Scientists 2009; Expedition 315 Scientists 2009); however, this is deeper than our sampling depth at this site. The ZTR index, which is a measure of the degree of reworking and hydraulic sorting, is quite low (Table 1; Fig. 7) to be a significant control on the observed change in composition. Furthermore, our average HMC values range from 7 to 9 , similar to the values obtained by Garzanti and Andò (2007b) for subduction orogens, indicating no significant loss due to diagenetic dissolution or sharp enrichments caused by hydraulic sorting effects. Therefore, we attributed the changes across the $1 \mathrm{Ma}$ boundary to a change in provenance and that the heavy mineral concentration and composition are mainly controlled by the source rock.

The volcanic minerals of the trench-wedge samples from Site C0006 account for about $60 \%$ of the total heavy minerals. In contrast, Unit II of the forearc and Unit Ib of the slope basin are richer in metamorphic mineral species such as the epidote group, garnet, kyanite and sillimanite, which decrease and increase at Sites C0002 and C0018, respectively, from bottom to top until the $1 \mathrm{Ma}$ boundary. Across this boundary into the younger section, the trends suddenly reverse at both sites (Fig. 9a). However, the clearest signal of compositional changes comes from the preponderance of blue sodic amphibole of the glaucophane-riebeckite series, indicative of erosion of high-pressure/temperaturetype metamorphic source rocks: in Unit II of the forearc basin and Unit Ib of the slope basin, blue amphiboles are frequent but nearly lacking in the related overlying units. Glaucophane was not observed in any of the river samples. The occurrence of glaucophane in the present geologic context within the outer zone of the Japanese Islands is limited to the high-grade blueschist/greenschist parts of the Shimanto and Sanbagawa Belts in central Shikoku (e.g. Aoki et al. 2008) except for Yaeyama Islands near Taiwan (Yossii 1935), which are too far to be source regions. Takeuchi (1988) reported the occurrence of some grains of glaucophane from sandstones in the central Kii peninsula in the catchment of one of the Kinokawa River. Mouri and Enami (1988) also recorded grains of amphibole, whose composition is close to glaucophane from the Sanbagawa Belt close to Tenryu River but not within its catchment. Tenryu River has the greatest petrological similarity to the samples of forearc basin Unit II and slope basin Unit Ib except for the lack of blue sodic amphibole. The highgrade metamorphic heavy mineral composition favours the Kumano/Kinokawa and, to a lesser extent, the Tenryu Rivers for the source of sediment for Unit I of the forearc basin and Fuji/Abe Rivers for the source of sediment for Unit Ia of the slope basin. These mineralogical observations suggest that the sands in the lower part of Unit I of the forearc basin are probably from the Tenryu and Kumano/Kinokawa Rivers but progressively dominated by the Kumano River until the upper part of the unit is overwhelmingly dominated by Kumano River component (Fig. 4). Similarly, after $1 \mathrm{Ma}$ in the upper slope basin section (i.e. Unit Ia at Site C0018), the sands are mostly dominated by the Fuji and Abe River components (Fig. 6). These data and inferred provenance can be explained by two alternative scenarios (Fig. 9b-d):

\{Scenario 1\} Constant flux from the Tenryu River to the two units over time; however, with a significantly increased influx of volcanic mineral species to the lower slope since ca. $1 \mathrm{Ma}$, likely to be derived from the Izu-Honshu collision zone along the trench axis. The sediment flux is now being dominated by Fuji and Abe Rivers and presumably was dominantly routed via the Suruga submarine canyon since ca. $1 \mathrm{Ma}$ (Fig. 9c). This scenario would be in line with interpretations derived previously by Fergusson (2003) from sands recovered from Sites 1175 and 1176 in the trench slope along the Muroto Transect off Shikoku Island more to the southwest of our study area. It also suggested that apparent contradictions of the data set presented by Clift et al. (2013), which has not detected any input from the Izu-Honshu collision zone even more to the southwest of our and Fergusson's (2003) study area, may have indeed simply resulted from spatial and temporal sampling resolution. Fergusson (2003) concluded that the sands in the trench slope were transported from the north-northwest down the inner slope rather than by axial transport along the Nankai Trough, and the mafic to intermediate volcanics are consistent with derivation from the east of the Izu-Bonin 
(a)
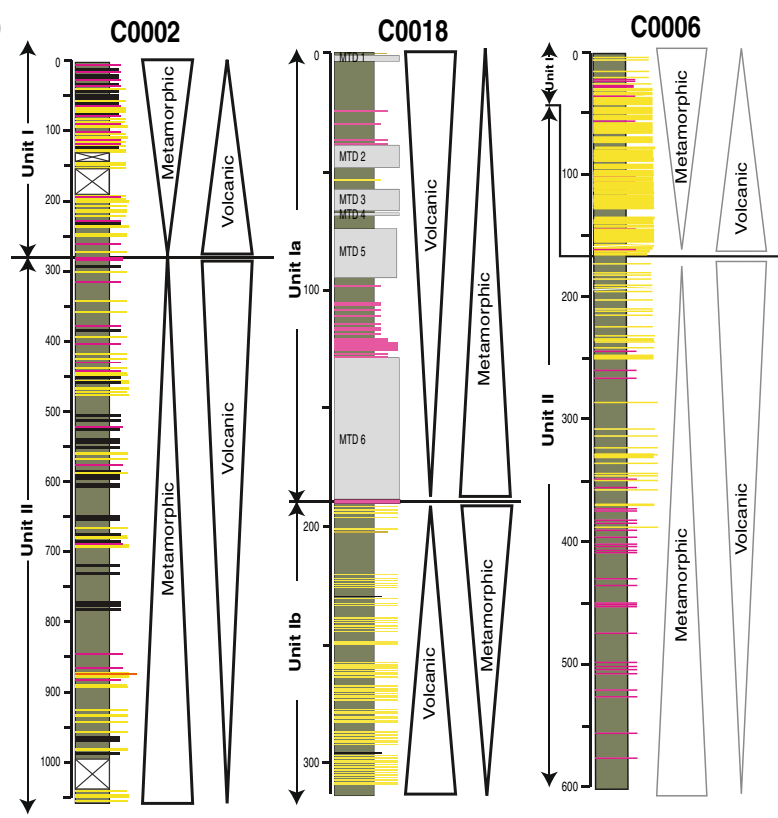

(c)

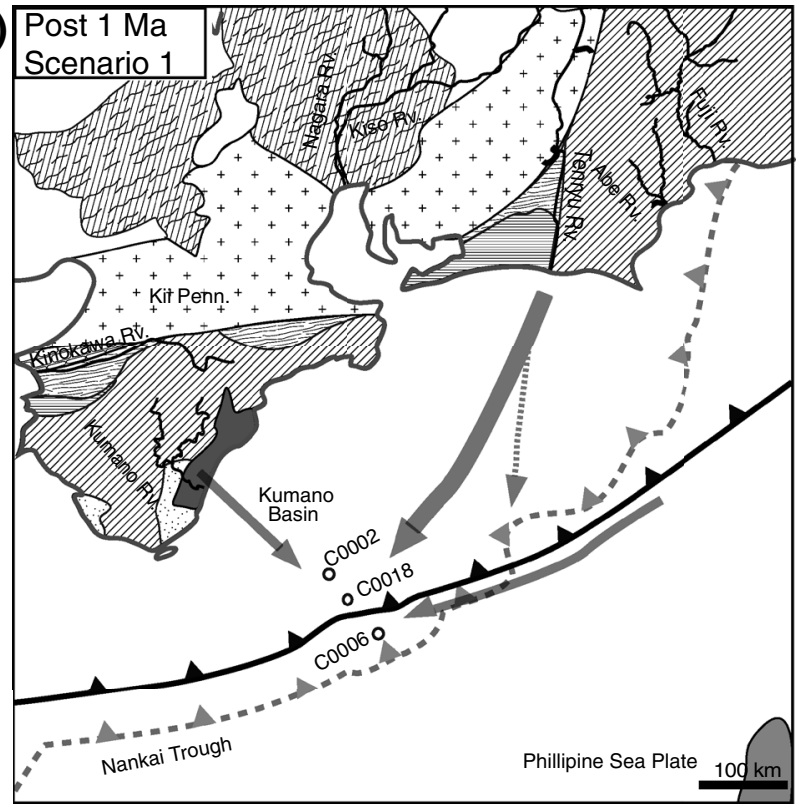

Fig. 9 Heavy mineral compositional trends at the three IODP sites (a), and the tectonic evolution model of the offshore Kii Peninsula showing the sediment dispersal patterns prior to $1 \mathrm{Ma}$ (b), and after $1 \mathrm{Ma}$ for two scenarios: scenario 1, without the influence of the forearc basin uplift (c), and scenario 2, as a result of Kumano (b)

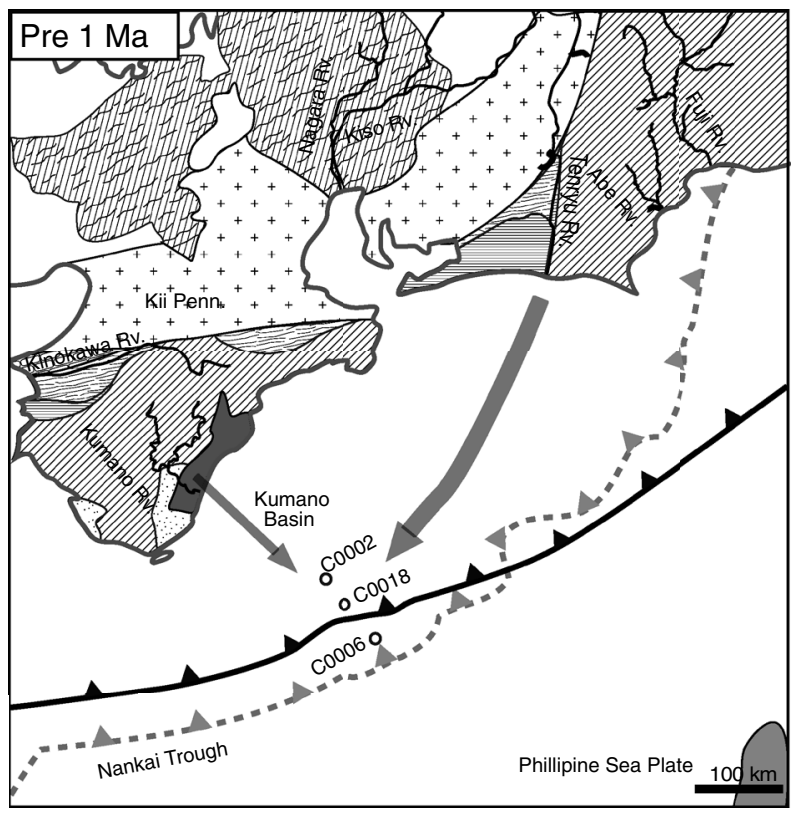

(d)

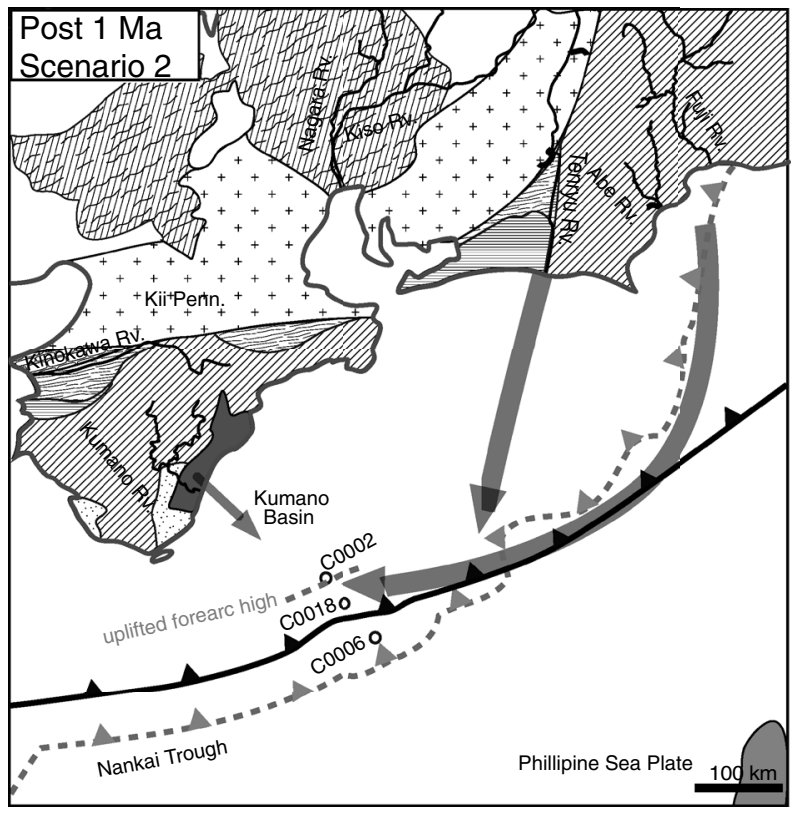

Basin edge uplift (d) on sediment routing. Positions of the subduction front through time are indicated as solid black and grey dashed lines for situations at around $1 \mathrm{Ma}$ and today, respectively. For legend of onland geologic patterns, see legend in Fig. 1 and Honshu Island Arc. Overall, uplift of Tertiary and older subduction complexes in southwest Japan occurred at approximately $15 \mathrm{Ma}$ on the Kii Peninsula (Hasebe et al. 1993; Tagami et al. 1995). At ca. 6-16 Ma, emergent southwest Japan was dominated by Cretaceous and younger plutonic and volcanic rock of the inner zone, which would imply a transverse delivery of sediment from the northwest. The last phase of the four accretion events at $1 \mathrm{Ma}$ is responsible for the influx of sediments along the Nankai Trough (Fergusson 2003). A constant sediment influx of the Tenryu River, however, may not be fully supported by 
present-day routing system of the Tenryu canyon that dissects the accretionary prism and enters the Nankai Trough further to the northeast of the studied Kumano Transect (Fig. 1). If correct, however, this scenario would therefore imply that the dissection of the Tenryu canyon occurred in geologically very recent time and that prior to the dissection, sediment routing from the Tenryu River was not into the trench but along the upper slope into the forearc and slope basin. Since samples from the lower prism Sites C0006 and C0007 do not record the trench-wedge sedimentation after accretion $0.436 \mathrm{Ma}$ (Screaton et al. 2009), this scenario cannot be conclusively tested.

\{Scenario 2\} The similar composition of sands with a distinct metamorphic mineral assemblages within the Kumano Basin and lower slope basin deposits prior to ca. $1 \mathrm{Ma}$, and the distinct differences between the two sites after ca. $1 \mathrm{Ma}$ can result from forearc high uplift, thereby limiting the flux of sediment by Kumano/Kinokawa Rivers into the slope basin. Sediment underthrusting, which began at ca. $1.3 \mathrm{Ma}$ and continued until after $1 \mathrm{Ma}$, resulted in the entire uplift of the Kumano Basin edge overlying the thick zone of underthrust sediment (Bangs et al. 2009). Gulick et al. (2010) showed that after some local shortening (beneath the southwest part of the Kumano Basin and seaward of the outer arc high) in the Early Quaternary, regional tilting of the Kumano Forearc basin occurred in the Middle to Late Quaternary, resulting in the landward shifting of depocenters during uplift and then basin infilling subsequent to uplift. The implication of this on sediment dispersal would be a confinement of sediments derived from onland southwest Japan into the Kumano Forearc basin, which were hitherto bypassing the forearc and transported transversely all the way to the slope basin and trench wedge (Fig. 9d).

A decrease of flux from the Kumano side as implied by the "forearc high blocking the sediment routing" scenario 2 is more likely and also consistent with the decrease in sedimentation rate from ca. $2.5 \mathrm{~cm} /$ year in Unit Ib to ca. $1 \mathrm{~cm} /$ year in Unit Ia at the slope basin site C0018. Also, episodic mass transport due to submarine landslide recorded by MTDs in the slope basin Unit Ia at Site C0018 (Strasser et al. 2011, 2012) is consistent with the forearc high uplift scenario, where mass wasting occurred more frequently after $1 \mathrm{Ma}$ due to slope instability of the steeper upper prism slope along the uplifted forearc high.

These interpretations, however, are based on conceptual mixing models for sand from different river systems. Sand populations within each river is complex, and the assumption that modern river systems are a good analogue for the ancient river systems may not completely hold for systems more than a million years back in time. Nevertheless, the presented scenarios are in good agreement with what has been proposed for the tectonic and lithostratigraphic evolution of the Nankai accretionary prism and thus considered to reflect the first-order relation between changing sediment routing systems and tectonics of the Nankai Forearc.

\section{Conclusions}

The petrographic sandstone data from the forearc basin, slope basin and trench-wedge sediments of the Nankai Trough accretionary wedge show systematic variations in bulk and heavy mineral composition in both space and time. The generic tectonic provenance for these sands is: a recycled orogen blended with dissected magmatic arc terranes.

There is clear evidence for both long-distance axial transport on the trench floor and direct transverse influx of sediment from the island arc feeding turbiditic sands to the slope basin studied at Site C0018. The Izu-Honshu collision zone serves as the principal detrital source region for the volcanic-rich sediments of younger $(<1 \mathrm{Ma})$ Unit Ia. Most of the sediments were probably derived from within the Fuji River drainage basin and funnelled through the Suruga submarine canyon to the trench environment. An overwhelming quantity of sediments in the deeper Unit Ib could have been derived from the Tenryu River drainage basin and submarine canyon system, which is located immediately west of the collision zone.

Two end-member hypotheses are proposed for explaining the observed abrupt facies, detrital modes and heavy mineral suite changes from Unit $\mathrm{Ib}$ to Unit Ia in the slope basin. Using end-member turbidite sand samples from the forearc basin and the trench wedge to constrain the sedimentation in the forearc and trench wedge, these two alternate hypotheses, when combined, clearly indicate a decoupling of sediment routing via long-distance axial transport and transverse flux of sediments around $1 \mathrm{Ma}$. This is most likely influenced by 
tectonic uplift of the forearc high decoupling sediment input into the Kumano Forearc basin from sediment supply to the upper and lower accretionary prism slope.

Acknowledgments This research used samples provided by the Integrated Ocean Drilling Program. Special thanks to Frowin Pirovino for the thin sections preparation. The river sand samples were collected mostly by high school students as a part of the "Sand for Students" outreach programmes promoted by the Japan Agency for Marine-Earth Science and Technology (JAMSTEC). This research project is supported by the Swiss National Science Foundation Grant PP00P2-133481.

Data are archived in www.pangaea.de (doi:10.1594/PANG AEA.830343).

\section{References}

Amano K (1991) Multiple collision tectonics of the South Fossa Magna in central Japan. Mod Geol 15:315-329

Andò S, Garzanti E, Padoan M, Limonta M (2012) Corrosion of heavy minerals during weathering and diagenesis: a catalog for optical analysis. Sediment Geol 280:165-178

Aoki K, Itaya T, Shibuya T, Masago H, Kon Y, Terabayashi M, Kaneko Y, Kawai T, Maruyama S (2008) The youngest blueschist belt in SW Japan: implication for the exhumation of the Cretaceous Sanbagawa high-P/T metamorphic belt. J Metamorph Geol 26:583-602

Bangs NLB, Moore GF, Gulick SPS, Pangborn EM, Tobin HJ, Kuramoto S, Taira A (2009) Broad, weak regions of the Nankai Megathrust and implications for shallow coseismic slip. Earth Planet Sci Lett 284(1-2):44-49

Basu A, McKay D, Gerke T (1988) Petrology and provenance of Apollo 15 drive tube 15007/8. Proceedings of the eighteenth lunar and planetary science conference (S. 283-298). Cambridge University Press, Cambridge, pp 283-298

Blum P, Okamura Y (1992) Pre-Holocene sediment dispersal systems and effects of structural controls and Holocene sea-level rise from acoustic facies analysis; SW Japan forearc. Mar Geol 108:295-322

Clift PD, Carter A, Nicholson U, Masago H (2013) Zircon and apatite thermochronology of the Nankai Trough accretionary prism and trench, Japan: sediment transport in an active and collisional margin setting. Tectonics 32:377-395

Critelli S, Le Pera E, Ingersoll RV (1997) The effects of source lithology, transport, deposition and sampling scale on the composition of southern California sands. Sedimentology 44:653-671

De Rosa R, Zuffa GG, Taira A, Leggett JK (1986) Petrography of trench sands from the Nankai Trough, southwest Japan: implications for long-distance turbidite transportation. Geol Mag 123:477-486

Dickinson WR (1970) Interpreting detrital modes of graywacke and arkose. J Sediment Petrol 40:695-707

Dickinson WR (1985) Interpreting provenance relations from detrital modes of sandstones. In: Zuffa GG (ed) Provenance of arenites (NATO ASI Series, Series C, 148). D. Riedel, Massachusetts, pp 333-361

Fergusson CL (2003) Provenance of Miocene-Pleistocene turbidite sands and sandstones, Nankai Trough, Ocean Drilling Program Leg 190. In: Mikada H, Moore GF, Taira A, Becker K, Moore JC, Klaus A (eds) Proceedings of the Ocean Drilling Program, Scientific Report 190/196. Reports 338. Integrated Ocean Drilling Program Management International Incorporation, Washington, pp 1-28
Folk RL (1968) Petrology of sedimentary rocks. Hemphill's, Austin, p 183

Gabriel A, Cox EP (1929) A staining method for the quantitative determination of certain rock minerals. Am Mineral 68:290-292

Garzanti E, Andò S (2007a) Plate tectonics and heavy mineral suites of modern sands. Dev Sedimentol 58:741-763

Garzanti E, Andò S (2007b) Heavy mineral concentration in modern sands: implications for provenance interpretation. Dev Sedimentol 58:507-545

Garzanti E, Andò S, Vezzoli G, Dell'Era D (2003) From rifted margins to foreland basins: investigating provenance and sediment dispersal across desert Arabia (Oman, U.A.E.). J Sediment Res 73(4):572-588

Garzanti E, Andò S, Vezzoli G, Lustrino M, Boni M, Vermeesch P (2012) Petrology of the Namib Sand Sea: long-distance transport and compositional variability in the wind-displaced Orange Delta. Earth Sci Rev 112:173-189

Gulick SPS, Bangs NLB, Moore GF, Ashi J, Martin KM, Sawyer DS, Tobin HJ, Kuramoto S, Taira A (2010) Rapid forearc basin uplift and megasplay fault development from 3D seismic images of Nankai Margin off Kii Peninsula, Japan. Earth Planet Sci Lett 300(1-2):55-62

Hasebe N, Tagami T, Nishimura S (1993) The evidence of along-arc differential uplift of the Shimanto accretionary complex: fission track thermochronology of the Kumano Acidic Rocks, Southwest Japan. Tectonophysics 224:327-335

Haughton PDW, Todd SP, Morton AC (1991) Sedimentary provenance studies. In: Morton AC, Todd SP, Haughton PDW (eds) Developments in sedimentary provenance studies. Geological Society of London Special Publications 57, London, pp 1-11

Higashino T (1990) The higher grade metamorphic zonation of the Sanbagawa metamorphic belt in central Shikoku, Japan. J Metamorph Geol 8:413-423

Houghton HF (1980) Refined techniques for staining plagioclase and alkali feldspars in thin section. J Sediment Petrol 50: 629-931

Hubert JF (1962) A zircon-tourmaline-rutile maturity index and the interdependence of the composition of heavy minerals assemblages with the gross composition and texture of sandstones. J Sediment Petrol 32(3):440-450

Ingersoll RV (1990) Actualistic sandstone petrofacies: discriminating modern and ancient source rocks. Geology 18:733-736

Kamata H, Kodama K (1999) Volcanic history and tectonics of the Southwest Japan Arc. Isl Arc 8:393-403

Karig DE, Sharman GF (1975) Subduction and accretion in trenches. Geol Soc Am Bull 86:377-389

Karig DE, Ingle JC, Haile N, Bouma AH, Moore JC, White SM, MacGregor I, Ellis H, Ujiie H, Ling HY, Koizumi I, Watanabe T, Yasui M (1975). In: Karig DE, Ingle JC (eds) Initial reports of the Deep Sea Drilling Program Leg 31. U.S. Government Printing Office, Washington, pp 927

Kimura JI, Stern RJ, Yoshida T (2005) Reinitiation of subduction and magmatic responses in SW Japan during Neogene time. Geol Soc Am Bull 117:969-986

Mahony SH, Wallace LM, Miyoshi M, Villamor P, Sparks RSJ, Hasenaka T (2011) Volcano-tectonic interactions during rapid plate-boundary evolution in the Kyushu region, SW Japan. Geol Soc Am Bull 123(11/12):2201-2223

Mange MA, Maurer HFW (1992) Heavy minerals in colour. Chapman and Hall, London, p 147

Mange-Rajetzky M, Oberhaensli R (1982) Detrital lawsonite and blue sodic amphibole in the molasse of Savoy, France and their significance in assessing alpine evolution. Schweiz Miner Petrogr Mitt 62:415-436

Marsaglia KM, Ingersoll RV, Packer BM (1992) Tectonic evolution of the Japanese Islands as reflected in modal compositions 
of Cenozoic forearc and backarc sand and sandstone. Tectonics 11(5):1028-1044

Maruyama S, Isozaki Y, Kimura G, Terabayashi M (1997) Paleogeographic maps of the Japanese Islands: plate tectonic synthesis from $750 \mathrm{Ma}$ to the present. Isl Arc 6:121-142

McLennan SM, Taylor SR, Eriksson KA (1983) Geochemistry of Archean shales from Pilbara Supergroup, Western Australia. Geochim Cosmochim Acta 47:1211-1222

Milliken KL, Corner EE, Marsaglia KM (2012) Data report: modal sand composition at site C0004, C0006, C0007, and C0008, IODP Expedition 316, Nankai accretionary prism. In: Kinoshita M, Tobin HJ, Ashi J, Kimura G, Lallemant S, Screaton EJ, Curewitz D, Masago H, Moe KT, Expedition 314/315/316 Scientists (eds) Proceedings of the Integrated Ocean Drilling Program 314/315/316. Integrated Ocean Drilling Program Management International Incorporation, Washington

Moore JC, Mascle A, Taylor E, Andreieff P, Alvarez F, Barnes R, Beck C, Behrmann J, Blanc G, Brown K, Clark M, Dolan J, Fisher A, Gieskes J, Hounslow M, McLellan P, Moran K, Ogawa Y, Sakai T, Schoonmaker J, Vrolijk P, Wilkens R, Wiiliams C (1988) Tectonics and hydrogeology of the northern Barbados Ridge: results from Ocean Drilling Program Leg 110. Geol Soc Am Bull 100:1578-1593

Moore GF, Taira A, Klaus A, Becker L, Boeckel B, Cragg BA, Dean A, Fergusson CL, Henry P, Hirano S, Hisamitsu T, Hunze S, Kastner M, Maltman AJ, Morgan JK, Murakami Y, Saffer DM, Sanchez-Gomez M, Screaton EJ, Smith DC, Spivack AJ, Steurer J, Tobin HJ, Ujiie K, Underwood MB, Wilson M (2001) New insights into deformation and fluid flow processes in the Nankai Trough accretionary prism: results of Ocean Drilling Program Leg 190. Geochem Geophys Geosyst 2(10):22

Moore GF, Park JO, Bangs NL, Gulick SP, Tobin HJ, Nakamura Y, Sato S, Tsuji T, Yoro T, Tanaka H, Uraki S, Kido Y, Sanada Y, Kuramoto S, Taira A (2009) Structural and seismic stratigraphic framework of the NanTroSEIZE Stage 1 transect. In: Kinoshita M, Tobin H, Ashi J, Kimura G, Lallement S, Screaton EJ, Curewitz D, Masago H, Moe KT, Expedition 314/315/316 Scientists (eds) Proceedings of the Integrated Ocean Drilling Program 314/315/316. Integrated Ocean Drilling Program Management International Incorporation, Washington

Mouri K, Enami M (1988) Chemical compositions of minerals from the Kichijosan and Joyama complexes in the Sanbagawa metamorphic belt, central Japan. Bull Nagoya Univ Mus 4:15-30 (in Japanese)

Nakajima T (1997) Regional metamorphic belts of the Japanese Islands. Isl Arc 6:69-90

Nechaev VP, Isphording WC (1993) Heavy-mineral assemblages of continental margins as indicators of plate-tectonic environments. J Sediment Petrol 63(6):1110-1117

Potter PE (1994) Modern sands of South America: composition, provenance and global significance. Geologische Rundshau 83:212-232

Saito K, Kato K, Sugi S (1997) K-Ar dating studies of Ashigawa and Tokuwa granodiorite bodies and plutonic geochronology in the South Fossa Magna, central Japan. Isl Arc 6:158-167

Expedition 314 Scientists (2009) Expedition 314 Site C0002. In: Kinoshita M, Tobin HJ, Ashi J, Kimura G, Lallemant S, Screaton EJ, Curewitz D, Masago H, Moe KT, Expedition 314/315/316 Scientists (eds) Proceedings of the Integrated Ocean Drilling Program 314/315/316. Integrated Ocean Drilling Program Management International Incorporation, Washington

Expedition 316 Scientists (2009a) Expedition 316 Site C0006. In: Kinoshita M, Tobin HJ, Ashi J, Kimura G, Lallemant S, Screaton EJ, Curewitz D, Masago H, Moe KT, Expedition 314/315/316 Scientists (eds) Proceedings of the Integrated Ocean Drilling Program 314/315/316. Integrated Ocean Drilliing Program Management International Incorporation, Washington
Expedition 316 Scientists (2009b) Expedition 316 Site C0004. In: Kinoshita M, Tobin HJ, Ashi J, Kimura G, Lallemant S, Screaton EJ, Curewitz D, Masago H, Moe KT, Expedition 314/315/316 Scientists (eds) Proceedings of the Integrated Ocean Drilling Program 314/315/316. Integrated Ocean Drilliing Program Management International Incorporation, Washington

Expedition 315 Scientists (2009) Expedition 315 Site C0002. In: Kinoshita M, Tobin HJ, Ashi J, Kimura G, Lallemant S, Screaton EJ, Curewitz D, Masago H, Moe KT, Expedition 314/315/316 Scientists (eds) Proceedings of the Integrated Ocean Drilling Program 314/315/316. Integrated Ocean Drilliing Program Management International Incorporation, Washington

Expedition 333 Scientists (2012). Expedition 333 Site C0018. In: Henry P, Kanamatsu T, Moe KT, Expedition 333 Scientists (eds) Proceedings of the Integrated Ocean Drilling Program 333. Integrated Ocean Drilliing Program Management International Incorporation, Washington

Expedition 338 Scientists (2013) NanTroSEIZE Stage 3: NanTroSEIZE plate boundary deep riser 2. In: Moore GF, Kanagawa K, Strasser M, Dugan B, Maeda L, Toczko S, Expedition 338 Scientists (eds) IODP Preliminary Reports 338. Integrated Ocean Drilliing Program Management International Incorporation, Washington DC, pp 81

Screaton E, Kimura G, Curewitz D, Moore G, Chester F, Fabbri O, Fergusson C, Girault F, Goldsby D, Harris R, Inagaki F, Jiang T, Kitamura Y, Knuth M, Li CF, Claesson Liljedahl L, Louis L, Milliken K, Nicholson U, Riedinger N, Sakaguchi A, Solomon E, Strasser M, Su X, Tsutsumi A, Yamaguchi A, Ujiee K, Zhao X (2009) Interactions between deformation and fluids in the frontal thrust region of the NanTroSEIZE transect offshore the Kii Peninsula, Japan: results from IODP Expedition 316 Sites C0006 and C0007. Geochem Geophys Geosyst 10:14

Seno T, Stein S, Gripp AE (1993) A model for the motion of the Philippine Sea plate consistent with NUVEL-1 and geological data. J Geophys Res 98:17941-17948

Shipboard Scientific Party (2001) Leg 190 summary. In: Moore GF, Taira A, Klaus A, Becker L, Boeckel B (eds) Proceedings of the Ocean Drilling Program, initial report 190. Ocean Drilling Program, College Station, $\mathrm{p} 87$

Strasser M, Moore GF, Kimura G, Kitamura Y, Kopf JA, Lallemant S, Park J, Screaton EJ, Su X, Underwood MB, Zhao X (2009) Origin and evolution of a splay fault in the Nankai accretionary wedge. Nat Geosci 2:648-652

Strasser M, Moore GF, Kimura G, Kopf AJ, Underwood MB, Guo J, Screaton EJ (2011) Slumping and mass transport deposition in the Nankai fore arc: evidence from IODP drilling and 3-D reflection seismic data. Geochem Geophys Geosyst 12(5):24

Strasser M, Henry P, Kanamatsu T, Thu MK, Moore GF, Expedition 333 Scientists (2012) Scientific drilling of mass-transport deposits in the Nankai accretionary wedge: first results from IODP expedition 333. In: Yamada Y, Kawamura K, Ikehara K, Ogawa Y, Urgeles R, Mosher D, Chaytor J, Strasser M (eds) Submarine mass movements and their consequences. Advances in Natural and Technological Hazard Research. Springer, Berlin, 31, pp 671-681

Tagami T, Hasebe N, Shimada C (1995) Episodic exhumation of accretionary complexes: fission-track thermochronologic evidence from Shimanto Belt and its vicinities, southwest Japan. Isl Arc 4:209-230

Taira A (2001) Tectonic evolution of the Japanese island arc system. Annu Rev Earth Planet Sci 29:109-134

Taira A, Niitsuma N (1986) Turbidite sedimentation in the Nankai Trough as interpreted from magnetic fabric, grain size, and detrital mode analysis. In: Kagami H, Karig DE, Coulbourn WT, DSDP Leg 87 Scientists (eds) Initial report, Deep Sea Drilling Program, Leg 87. U.S. Government Printing Office, Washington, pp 611-632 
Taira A, Okada H, Whitaker JH, Smith AJ (1982) The Shimanto Belt of Japan: Cretaceous-lower Miocene active-margin sedimentation. In: Leggett JK (ed) Trench-forearc geology (Geological Society of London Special Publication). Geological Society of London, London, pp 5-26

Taira A, Katto J, Tashiro M, Okamura M, Kodama K (1988) The Shimanto Belt in Shikoku, Japan: evolution of Cretaceous to Miocene accretionary prism. Mod Geol 12:5-46

Taira A, Hill IA, Firth JV, Berner U, Brueckmann W, Bryne T, Chabernaud T, Fisher A, Foucher J, Qamo T, Gieskes JM, Hyndman RD, Karig DE, Kastner M, Kato Y, Lallemant S, Lu R, Maltman AJ, Moore GF, Moran K, Olasson G, Owens WH, Pickering KT, Siena F, Taylor E, Underwood MB, Wilkinson C, Yamano M, Zhang J (1991) Proceedings of the Ocean Drilling Program, initial reports 131. Ocean Drilling Program, College Station

Takahashi M, Saito K (1997) Miocene intra-arc bending at arc-arc collision zone, central Japan. Isl Arc 6:168-182

Takeuchi M (1988) Alkali amphibole-bearing schist in the Sanbagawa metamorphic terrane, central Kii Peninsula. Ganko 83:69-76 (in Japanese with English abstract)

Tobin HJ, Kinoshita M (2006) NanTroSEIZE: the IODP Nankai trough seismogenic zone experiment. Sci Drill 2:23-27

Underwood MB, Fergusson CL (2005) Late Cenozoic evolution of the Nankai trench-slope system: evidence from sand petrography and clay mineralogy. In: Hodgson DM, Flint SS (eds) Submarine slope systems: processes and products. Geological Society London Special Publications 244. Geological Society of London, London, pp 113-129

Underwood MB, Moore GF (1995) Trenches and trench-slope basins. In: Busby CJ, Ingersoll RV (eds) Tectonics of sedimentary basins. Blackwell Science, Cambridge, pp 179-219

Underwood MB, Pickering KT (1996) Clay-mineral provenance, sediment dispersal patterns, and mudrock diagenesis in the Nankai accretionary prism, southwest Japan. Clays and Clay Minerals 44(3):339-356

von Huene R, Lallemant S (1990) Tectonic erosion along the Japan and Peru convergent margins. Geol Soc Am Bull 102(6):704-720

Winkler HGF (1976) Petrogenesis of metamorphic rocks. Springer, Berlin, p 334

Yamamoto Y, Kawakami S (2005) Rapid tectonics of the Late Miocene Boso accretionary prism related to the Izu-Bonin arc collision. Isl Arc 14:178-198

Yossii M (1935) On some glaucophane rocks from the Ryukyu archipelago. Science reports of the Tohoku Imperial University. 2nd series, Geology 16:225-248

Zuffa GG (1980) Hybrid arenites: their composition and classification. J Sediment Petrol 50:21-29 